\title{
Un 'disegno' alternativo: linguaggi, strumenti e metodologie di un'esperienza didattica ai tempi del Covid-19
}

\author{
Giuseppe D'Acunto \\ Antonio Calandriello
}

\section{Abstract}

II presente saggio nasce dall'esigenza di condividere una insolita esperienza di un corso di disegno svolto totalmente da remoto durante la pandemia da Covid- 19, all'interno dell'offerta didattica di un corso di laurea magistrale in Architettura.

Un'esperienza da subito accettata come una sfida piuttosto che come una disgrazia e che ha imposto un totale ripensamento dei contenuti e dei linguaggi di comunicazione, rifiutando a prescindere l'idea di adattare quelli già consolidati in un nuovo formato didattico.

II corso ha voluto quindi sperimentare e fondare un nuovo approccio rappresentativo - e dunque conoscitivo - dell'architettura, individuando alcuni protocolli rappresentativi tesi a costruire complessi modelli digitali e comunicarne i propri valori attraverso delle 'immagini'.

Attraverso l'analisi critica di alcuni casi-studio paradigmatici esposti durante le lezioni teoriche e le comunicazioni offerte dal docente e da studiosi invitati appositamente, è stato offerto un ampio regesto degli studi critici e degli approcci metodologici sviluppatisi negli ultimi anni sul tema del digitale in architettura, sia in Italia che all'estero, come premessa teorica alla fase sperimentale e laboratoriale. In particolare, gli ambiti tematici trattati, sia dal punto vista teorico che nelle relative esercitazioni degli studenti, sono stati tre: 'complessità formale', 'luce e spazio architettonico' e 'l'architettura e le sue immagini'. All'interno di questi ambiti, così come narrati in questo saggio, lo studente ha potuto sperimentare e verificare il potere delle immagini di architettura all'interno di un articolato e complesso impianto narrativo.

\section{Parole chiave}

modellazione digitale, fotogrammetria digitale, fotoinserimento, rendering.

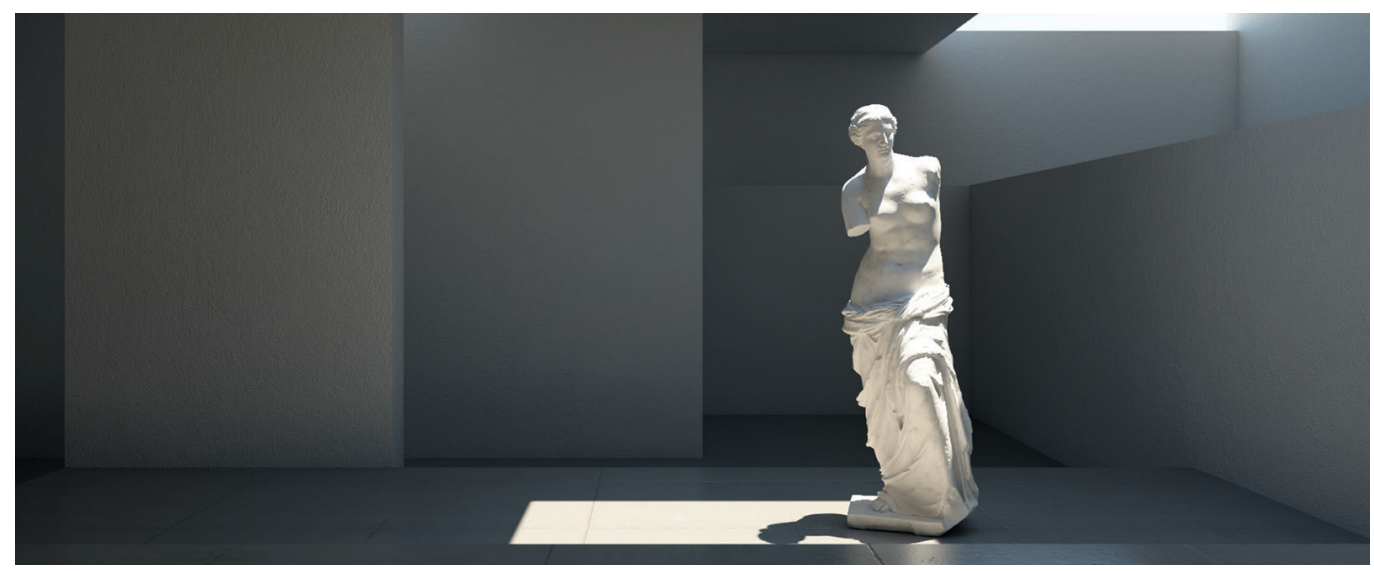


La didattica del disegno, nelle sue diverse definizioni e declinazioni, è forse quella che con maggiore difficoltà si è adattata alla modalità telematica che l'ultimo anno, con la pandemia da Covid-19, ci ha imposto. Eppure, abbiamo erogato diverse ore di disegno nei corsi di laurea che ci vedono coinvolti, inventandoci nuove forme di comunicazione a distanza con $\mathrm{i}$ nostri studenti basate su "... linguaggi differenti da quelli consolidati" salvaguardando, in ogni caso, gli obbiettivi formativi degli stessi corsi. In alcuni casi, oltre a una metodologia didattica diversa, abbiamo voluto indagare e sperimentare nuovi temi di riflessione e di lavoro ai quali il lockdown ci ha imposto di guardare con più attenzione.

Il presente saggio nasce dall'esigenza di condividere un'insolita esperienza di un corso di disegno [I] svolto totalmente da remoto, all'interno dell'offerta didattica di un corso di laurea magistrale in Architettura, dove il docente non ha mai fisicamente incontrato gli studenti, nemmeno per l'esame finale e dove gli esiti dei lavori dei discenti, paradossalmente ottimi o addirittura migliori di quanto ottenuto negli anni precedenti in corsi analoghi e in presenza, hanno da un lato rassicurato sulla riuscita di questo esperimento didattico ma dall'altro hanno posto interrogativi costringendo chi scrive a rivedere le sue posizioni, quasi ideologiche, e la sua profonda riluttanza verso la didattica del disegno erogata da remoto.

La prima sfida accettata nella progettazione del corso, avvenuta nella piena consapevolezza di svolgere l'intero carico didattico da remoto, è stata quella di ripensare i contenuti del corso, ancora saldamente ancorati agli obbiettivi formativi del progetto didattico, evitando di adattare a un insolito formato, quello telematico appunto, gli stessi contenuti già ampiamente sperimentati negli anni precedenti. II corso ha voluto quindi sperimentare e fondare un nuovo approccio rappresentativo - e dunque conoscitivo - dell'architettura. In questa chiave esegetica, l'intenzione del corso è stata quella di individuare alcuni protocolli rappresentativi tesi a costruire complessi modelli digitali e comunicarne i propri valori attraverso delle 'immagini'.

Attraverso l'analisi critica di alcuni casi-studio paradigmatici esposti durante le lezioni teoriche e le comunicazioni offerte dal docente e da studiosi invitati appositamente, è stato offerto un ampio regesto degli studi critici e degli approcci metodologici sviluppatisi negli ultimi anni sul tema del digitale in architettura, sia in Italia che all'estero, come premessa teorica alla fase sperimentale e laboratoriale.

Fig. I. Sequenza delle operazioni per la creazione del modello poligonale con texture con Agisoft Metashape. Dall'alto verso il basso e da sinistra a destra: caricamento delle immagini; costruzione della sparse points cloud; inserimento dei marker creazione della dense cloud creazione della cloud; creazione della mesh e della texture (elaborazioni digitali d Mometti, Magl, Chiar Mometti, Melissa Rossetti).
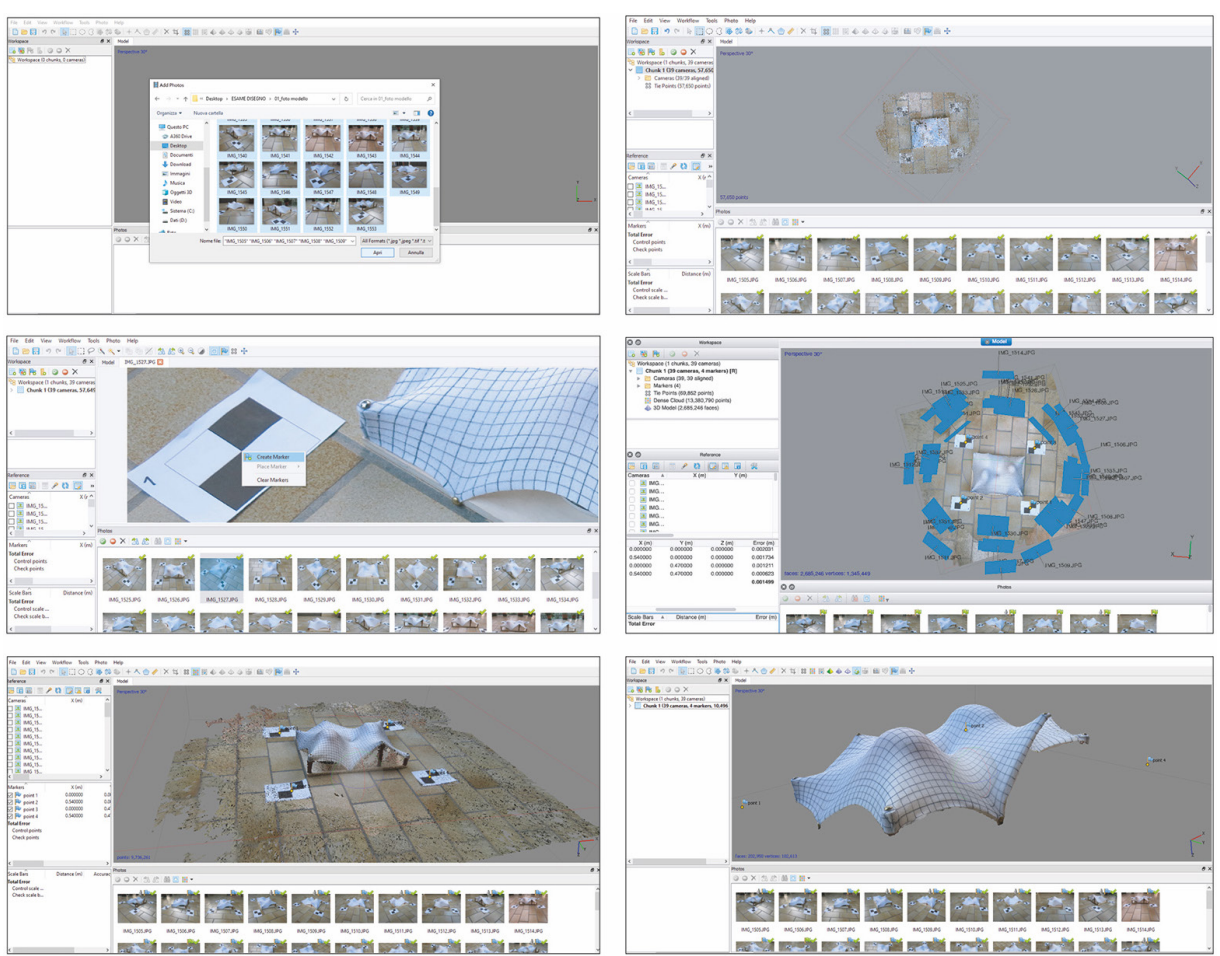
In particolare, gli ambiti tematici trattati, sia dal punto vista teorico che nelle relative esercitazioni degli studenti, sono stati tre: 'complessità formale', 'luce e spazio architettonico' e 'l'architettura e le sue immagini'.

II primo caso, 'complessità formale', si è concentrato sull'analisi di alcuni esempi di architettura contemporanea per verificare come l'incontro tra geometrie, anche non tradizionali, e la modellazione digitale abbia stimolato la mente dell'architetto verso una capacità inventiva e a una sperimentazione formale senza precedenti.

Lo studente, riflettendo intorno a questi temi, è stato invitato a verificare ed esercitare la sua capacità di invenzione formale mediante la creazione di un modello fisico dalla configurazione geometrico/formale molto complessa, per poi tradurlo in modello digitale mediate la fotogrammetria digitale e, successivamente, manipolarlo nello spazio virtuale con gli strumenti della modellazione digitale per ottenere una forma architettonica estremamente complessa. In questo contesto, non è importante l'origine dei modelli utilizzati, ma la possibilità di tradurli in algoritmi elettronici capaci di plasmare digitalmente una forma architettonica, e la geometria, nelle sue accezioni teoriche più complesse, è proprio alla base di questo sistema di traduzione. In sostanza si tratta di un approccio progettuale che inverte, intenzionalmente, le fasi creative e operative: la 'complessità formale'è plasmata e articolata manualmente dallo studente, nell'intento di riprendere un contatto fisico con la materia e con il corpo dell'architettura, per poi riversarla in ambiente digitale dove poterla liberamente manipolare e trasformare.
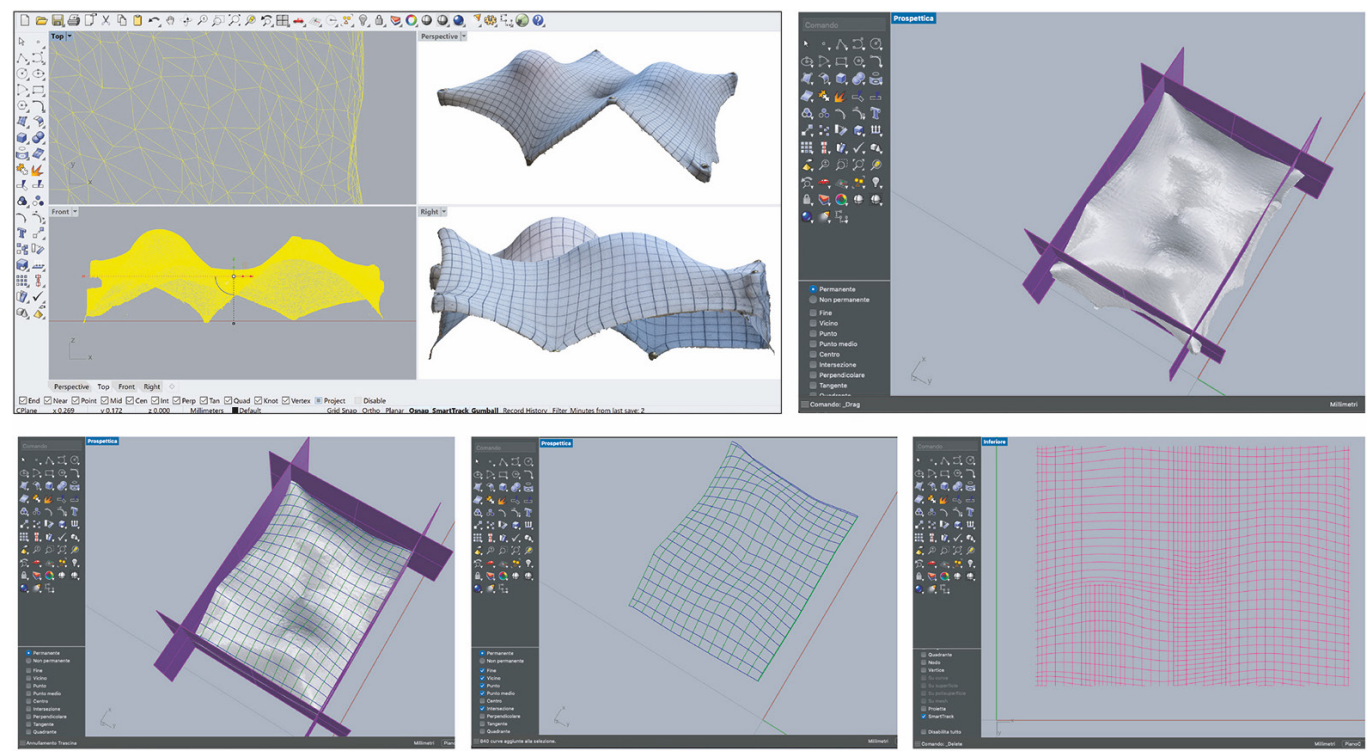

Agli studenti è stato quindi richiesto di modellare fisicamente una superficie freeform, utilizzando un tessuto elastico e dei semplici elementi 'modificatori' (puntine da disegno, fil di ferro, centine in cartonlegno, ecc.) che simulavano delle forze agenti sulla superficie. Stabilita la forma desiderata, sono stati apposti opportuni marker e successivamente la superficie è stata rilevata attraverso l'uso della fotogrammetria digitale. Le fotografie, realizzate rispettando le regole di sovrapposizione e distribuzione spaziale imposte dai software Structure from motion (SfM), sono state elaborate attraverso l'utilizzo di Agisoft Metashape. Le foto sono state quindi allineate e successivamente sono state inserite le coordinate dei marker in modo da ottenere un modello finale correttamente orientato e metricamente attendibile. La scelta dell'inserimento dei marker successivamente all'allineamento è metodologica, in questo modo Metashape è in grado di visualizzare automaticamente i marker in ciascuna foto e all'utente non resta che confermarne la posizione, rendendo più rapido questo passaggio. A seguire, si è generata ex novo la sparse points cloud (l'individuazione dei punti 
Fig. 3. Traduzione

della superficie da

modello numerico

quello matematico.

Dall'alto verso il basso

e da sinistra a destra:

esempio di curva di

sezione; ricostruzione

della curva di sezione;

creazione della superficie

attraverso il comando

network; verifiche della

corrispondenza tra

il modello mesh di

partenza (in azzurro) e la

superficie NURBS creata

(in grigio), (elaborazioni

digitali di Katharina Magi,

Chiara Mometti, Melissa

Rossetti).

Fig. 4. Tassellazione della superficie NURBS con Paneling Tools di Rhino.

(elaborazione di Alex

Dallatorre e Alessia

Mazzarano).

Fig. 5. Tassellazione della superficie NURBS con Grasshopper. In alto l'algoritmo

utilizzato, sotto le fasi

di suddivisione della

superficie utilizzando

diperfie utilzzando

(elaborazioni digitali di

Marco Bonotto, Anna

Calia Di Pinto, Alessia

Toniolo)
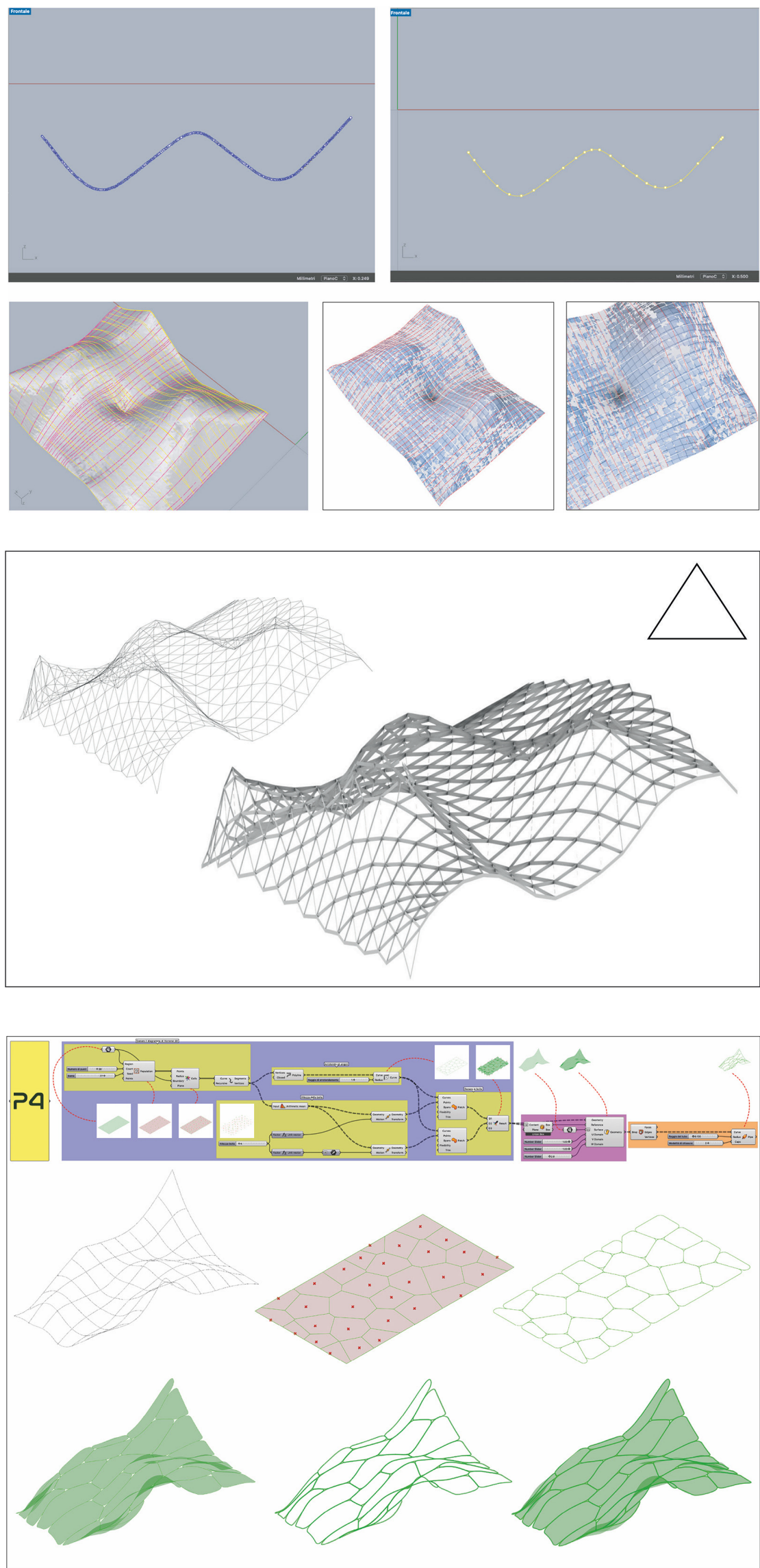
omologhi, detti tie points), quindi la dense cloud, il modello poligonale mesh e infine è stata creata la texture (fig. I).

II modello esportato in file .obj insieme alla sua texture è stato importato allinterno dello spazio digitale del software di modellazione NURBS Rhinoceros. La mesh è stata successivamente ripulita e attraverso il comando contour sono state create delle sezioni longitudinali e trasversali, tendo cura di intensificarle nei punti di curvatura massima. Successivamente queste sezioni sono state ricostruite manualmente attraverso l'utilizzo del comando curve: interpolate points, si è preferita adottare questa strategia invece che automatizzare il processo, per ottenere un maggior controllo sulla distribuzione dei 'punti di controllo' delle curve e intensificarle laddove il raggio di curvature fosse minore (fig. 2). Le curve ricostruite sono state utilizzate per generare la nuova superficie NURBS attraverso il comando surface from network of curves (fig. 3). Questo passaggio è servito allo studente per prendere consapevolezza delle diverse tipologie di modelli (discreto, poligonale, matematico) che possono descrivere una medesima superficie, quali sono le caratteristiche e come si comportano alle modifiche.

Infine, il modello è stato sottoposto a un processo di tassellazione attraverso gli strumenti di paneling di Rhino o di Grasshopper nei casi più articolati, questo step è stato particolarmente utile al fine di rendere la superficie nuovamente poligonale e verosimile a una struttura architettonica a tutti gli effetti (figg. 4, 5).

In una seconda tappa di questa prima esercitazione, gli studenti sono stati invitati a immaginare di inserire questa forma complessa, derivante dal processo appena descritto, in un ambiente strutturato. Ogni studente è stato quindi invitato a scegliere un spazio definito da diverse funzioni e caratteristiche morfologiche (uno spazio urbano, un interno architettonico, un luogo fisico rappresentato e controllato da una rigorosa prospettiva) inquadrato all'interno di un'immagine (pittorica o fotografica) a quadro verticale dalla quale fosse possibile ricavare in modo univoco il riferimento prospettico per poi procedere alla restituzione prospettica e quindi ottenere lo spazio e le sue diverse componenti rappresentate in vera forma e dimensione (fig. 6).

A questo punto è stato costruito il modello digitale riguardante gli ingombri dello spazio prescelto al cui interno è stato inserito il modello tassellato precedentemente ricavato.

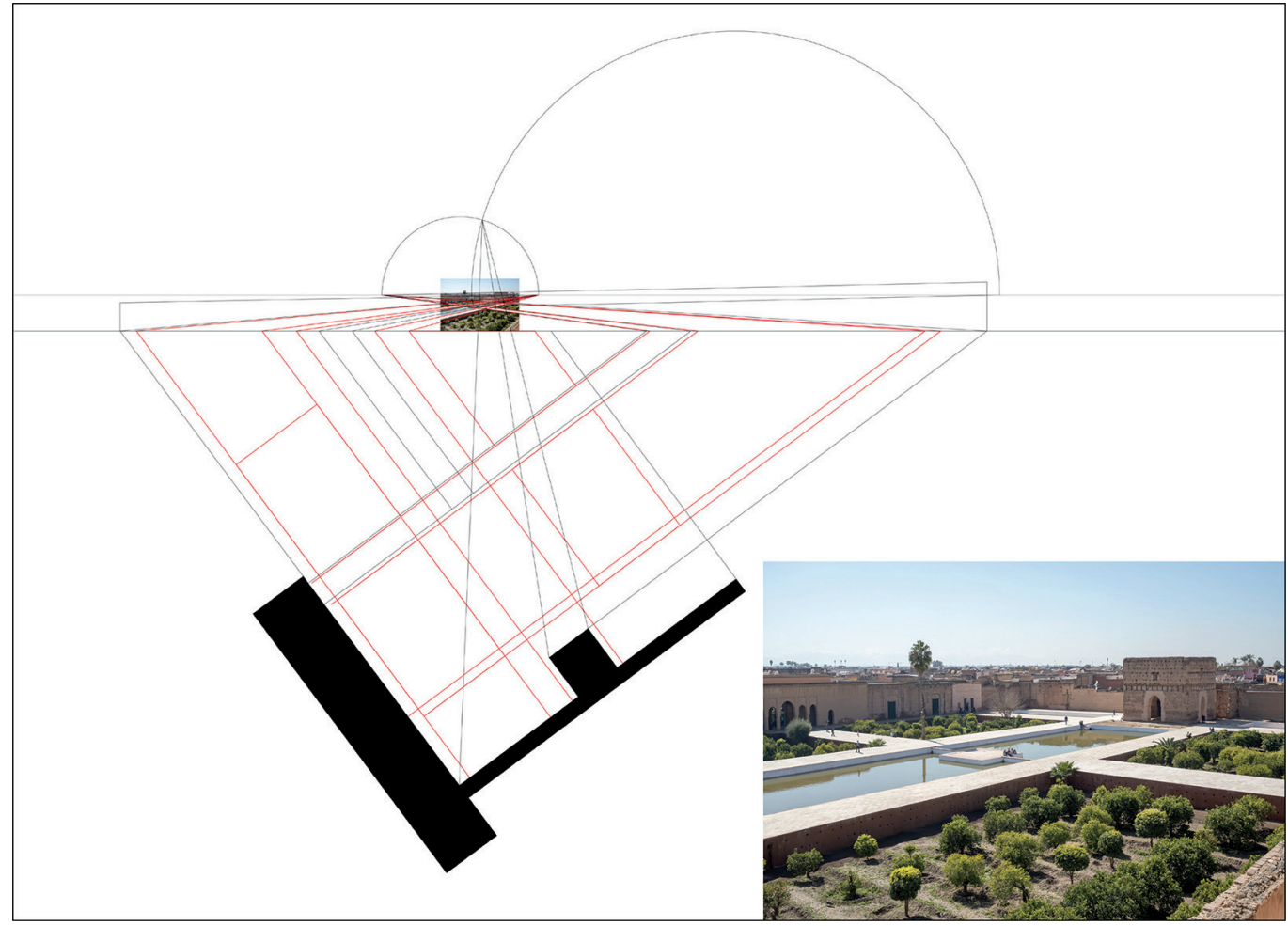


Grazie alle informazioni ricavate dalla restituzione prospettica è stato possibile collocare la camera nella giusta posizione spaziale (fig. 7). La verifica della corretta lunghezza focale della camera digitale, laddove non in possesso di tale informazione, è avvenuta posizionando l'immagine, in semitrasparenza, verticalmente sulla retta 'fondamentale' e posizionandosi nel centro di proiezione (fig. 8). Successivamente il modello è stato importato in Cinema4D o 3ds Max [2], sono state impostate le luci coerentemente all'immagine di partenza, applicati i materiali scelti e infine è stata renderizzata la scena. A conclusione sono state sovrapposte le due immagini: quella del rendering a quella di partenza (fig. 9).

Un esercizio estremamente complesso e affascinate, da subito inteso come il perfetto connubio tra una metodologia di lavoro tradizionale, come appunto la restituzione prospettica, e l'innovazione espressa nella modellazione digitale e nella renderizzazione. La capacità di entrare nella struttura più intima delle immagini scelte, di ricostruirne lo spazio rappresentato, controllarlo geometricamente e di trovare un raccordo prospettico tra la nuova forma inserita e il contesto già strutturato, è stato percepito e accolto dagli studenti come un esercizio dal forte carattere sperimentale e progettuale e come un approccio metodologico che, nel suo assoluto rigore geometrico, ha scongiurato e allontanato qualunque forma di automatismo nella fase costruttiva dell'immagine complessiva, lo stesso automatismo acritico che troppo spesso caratterizza i tentativi mal riusciti di fotoinserimenti.

La seconda parte del corso dedicato al tema della luce, è stata inaugurata dalla conferenza della professoressa Franca Pittaluga, già docente di Progettazione Architettonica presso I'Università luav di Venezia, che ha proposto agli studenti il risultato delle sue lunghe e appassionate ricerche incentrate sul ruolo della luce naturale nella progettazione degli spazi architettonici contemporanei. La studiosa ha proposto un'intensa riflessione sulla luce intesa come fondamentale agente nella caratterizzazione degli spazi ideati per l'uomo attraverso la storia: al pari di altri strumenti progettuali (quali la proporzione, l'articolazione delle parti, il dettaglio degli elementi) la luce naturale viene assunta e studiata quale veicolo di qualità che l'architetto è in grado di mettere in azione per assegnare agli ambienti una valenza distintiva, a volte irripetibile. Gli studi proposti da Franca Pittaluga percorrono a ritroso l'azione intenzionale del progettista, mettendo a confronto spazi modellati dalla luce e disegnati dall'ombra per decodificare gli artifici architettonici che vi stanno all'origine: questi, secondo
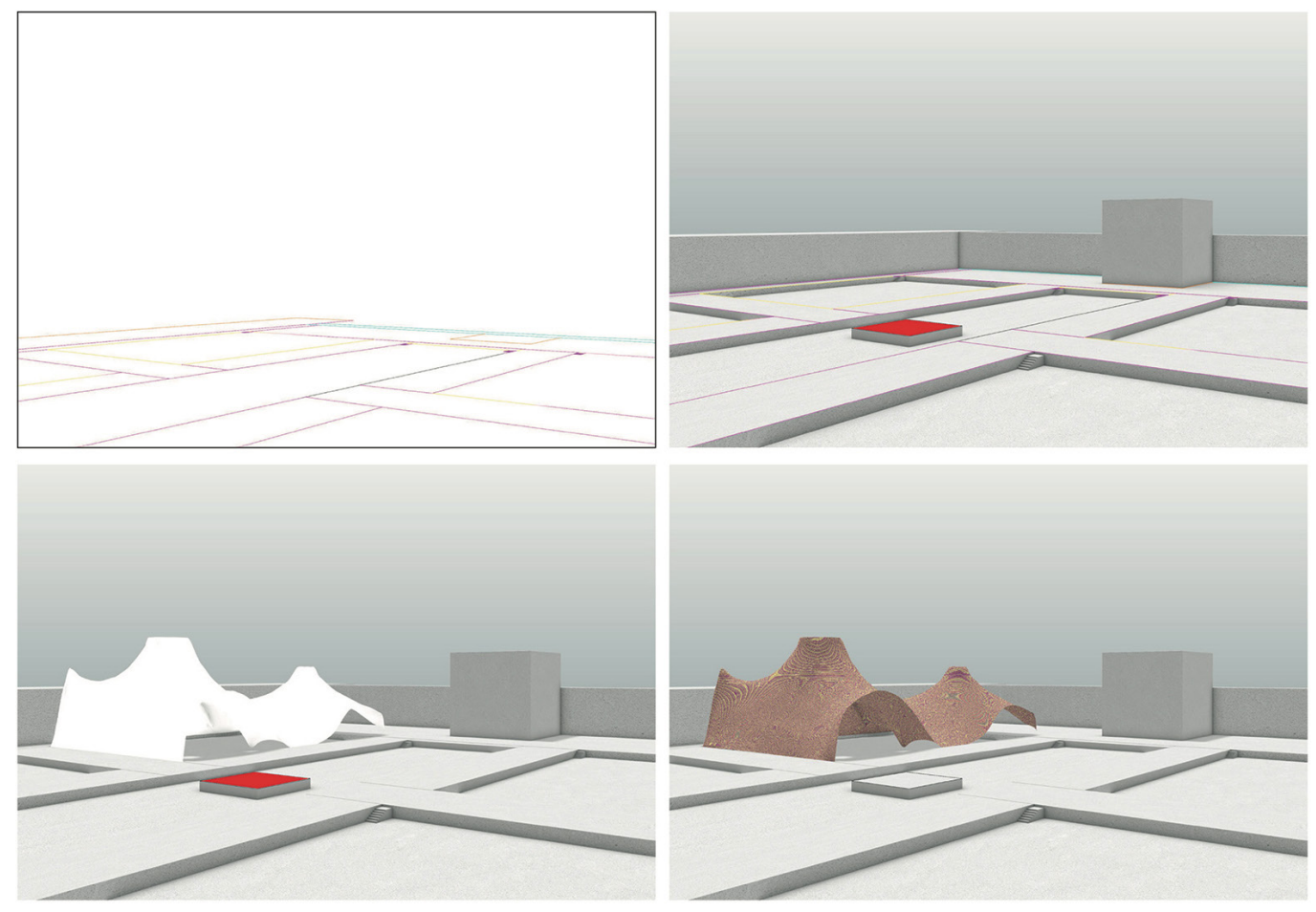
i casi, rimandano a determinate strategie strutturali, particolari conformazioni di sezione, peculiari opzioni sullinvolucro, o innovative sperimentazioni sui materiali [Pittaluga, Scavuzzo 2007; Pittaluga 2014].

Le riflessioni proposte da Franca Pittaluga si sono costituite come un'imprescindibile premessa alla successiva esercitazione proposta agli studenti: il lavoro di modellazione della luce messo in campo è stato guidato da un approccio critico e progettuale che ha trovato una immediata verifica in ambiente digitale nelle sue relazioni con le diverse configurazioni architettoniche prese in esame e con i caratteri materici e cromatici degli spazi.

In sostanza, gli studenti sono stati chiamati a prefigurare scenari, mediante dei render di ambienti architettonici in cui la luce rivestisse un importante e indiscusso ruolo nell'organizzazione compositiva degli spazi. In molti casi, gli studenti hanno preferito concentrare la loro ricerca su dei progetti sviluppati in altri corsi per poterne verificare il comportamento della luce all'interno di una simulazione digitale: si sono aperti scenari insoliti e imprevisti che, paradossalmente, erano solo stati immaginati ma mai verificati nelle precedenti esperienze didattiche. In altri casi, gli studenti hanno preferito concentrarsi sulla verifica della luce in alcuni spazi progettati da architetti contemporanei ma mai realizzati, lasciando spesso irrisolto proprio il tema della luce.

Fig. 8.Verifica dell'impianto prospettico e risultato finale (a destra), (elaborazioni digitali di Alberto Baccin e Gaetano Sedicino)
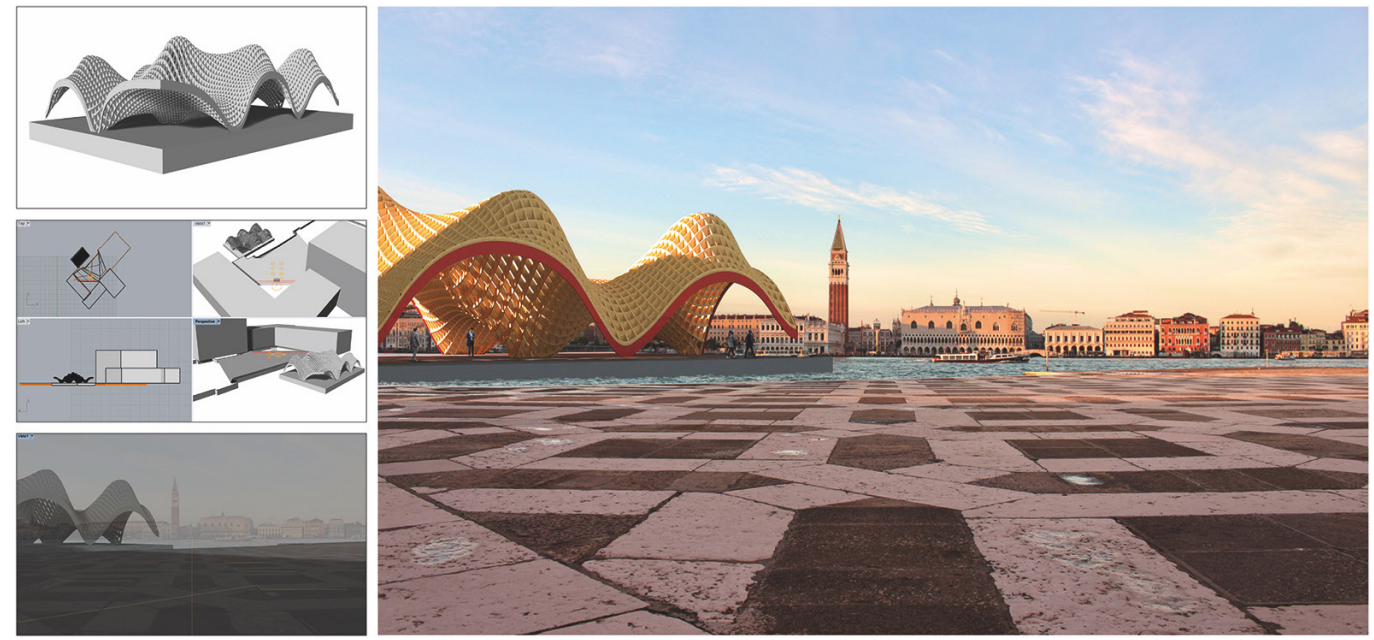

Questo è il caso del Danteum progettato nel 1938 Giuseppe Terragni (1904-1943) e Pietro Lingeri (1894-1968), tributo all'opera di Dante, ma mai realizzato [Schumacher 1983]. $\grave{E}$ un'opera dal forte carattere simbolico, che evoca i luoghi principali della Divina Commedia attraverso grandi spazi che, tramite materiali e leggi architettoniche, dovevano esprimerne il significato. In questa fase gli studenti hanno ricreato virtualmente gli spazi architettonici e all'interno dei diversi software di render utilizzati è stato ricreato il set di luci corrispondente a quello solare, tenendo conto dell'esposizione solare e della collocazione del progetto. L'operazione dell'analisi del comportamento della luce solare, oltre a quanto enunciato, ha avuto un risvolto pratico, in quanto è stata attività propedeutica alla realizzazione delle immagini finali (figg. I0, I I).

Nell'ultima parte del corso, intitolata L'architettura e le sue immagini, è stata proposta agli studenti una riflessione intorno al tema delle immagini di architettura e alla loro capacità di narrarne il percorso progettuale, evidenziarne il rapporto con l'architetto, comunicarne i valori espressivi e formali attraverso viste di insieme e di dettaglio. In tal senso, è stato riconosciuto all'immagine soggettiva, quella osservatore dipendente, un ruolo fondamentale nelle sue molteplici forme assunte nel corso della storia: dalla prospettiva rinascimentale alla fotografia fino agli attuali render. Quindi, la costruzione di un'immagine virtuale è stata intesa e assunta come uno straordinario strumento di prefigurazione di uno spazio costruito, allontanandosi, anche in questo caso, da qualunque forma di automatismo digitale per co- 
stituirsi come 'nuova immagine soggettiva', con un proprio statuto estetico, e quindi legarsi, nell'impianto metodologico e nella sua capacità espressiva e comunicativa, alle rappresentazioni fotografiche. Per sottolineare questo fondamentale nesso tra due impianti metodologici solo apparentemente diversi e abituare lo studente a sovrapporre il concetto di render a quella di fotografia di architettura di autore, la fase la fase sperimentale è stata preceduta da una illuminante conferenza del maestro Giovanni Chiaramonte. Nella sua comunicazione, il celebre fotografo varesotto ha raccontato della sua lunga esperienza al fianco di Alvaro Siza e del suo tentativo di costruire un personale e intimo racconto dell'architettura del maestro portoghese attraverso degli scatti capaci di incorniciare e intrappolare il senso e il significato più profondo di quelle forme nel loro dialogo con la luce, con la materia e con lo spazio [Chiaramonte, Siza 2018].

L'attenzione in questa parte si è focalizzata sull'uso delle camere dei software di rendering (principalmente Cinema4D e 3ds Max abbinato al motore di rendering V-Ray), sulla cura dell'inquadrature e sull'uso congruo dei materiali. Gli studenti, avendo in precedenza studiato e calibrato le luci, si sono concentrati sugli aspetti legati alla materia, confrontandosi con la difficile scelta delle texture e la calibrazione dei singoli parametri (come il bump, 'riflessione' e 'riflettanza' per citarne alcuni) che regolano la resa dei materiali. Inoltre, hanno avuto la possibilità di poter sperimentare materiali diversi rispetto a quelli previsti dai progetti iniziali, sperimentando così il variare, talvolta profondo, dell'essenza stessa dell'architettura (fig. I2).
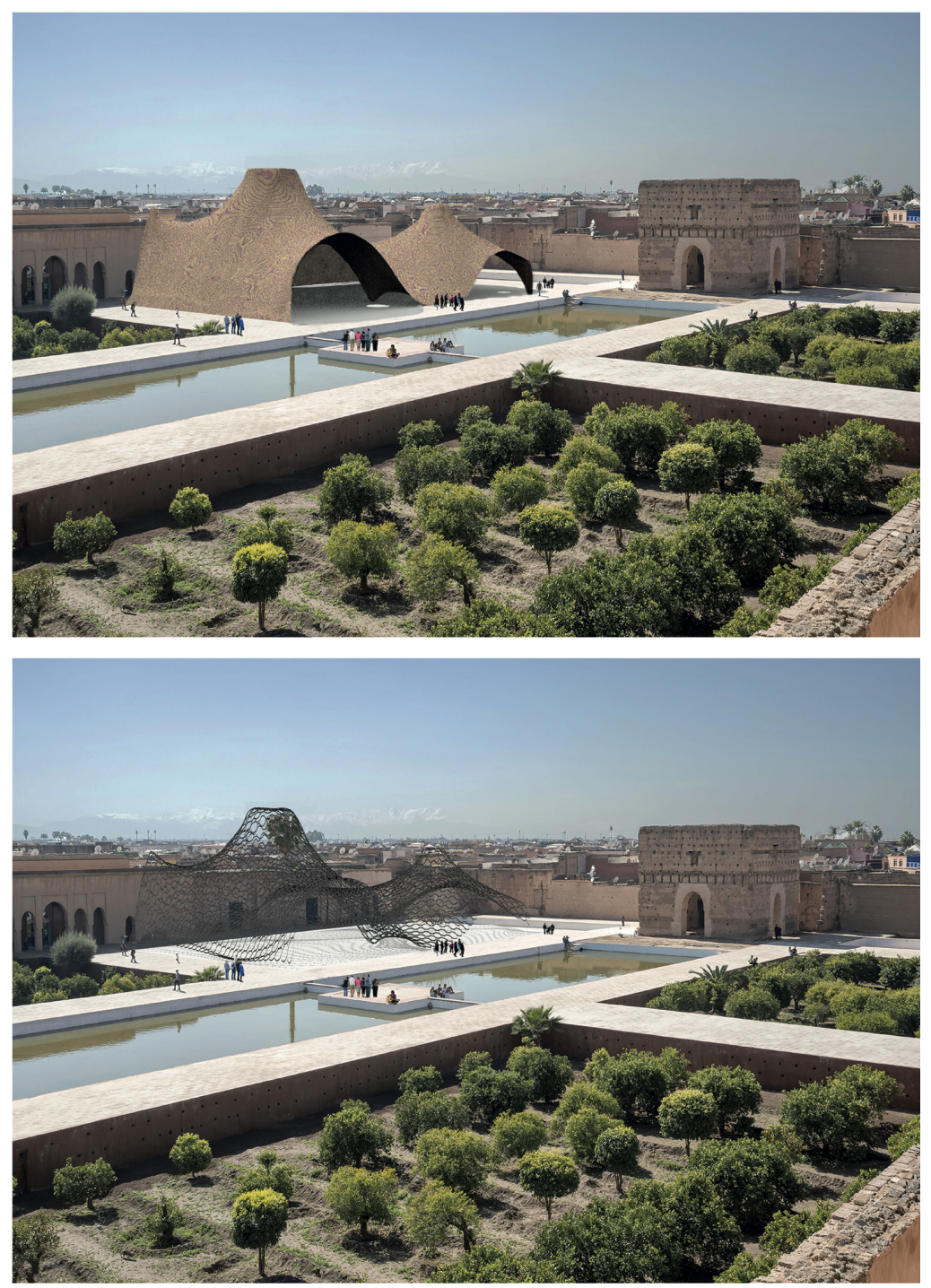
Fig. 10. In alto: elaborazioni di immagini di archivio del Danteum. Sotto:

modello digitale (elaborazione di Alex Dallatorre Alessia Mazzarano).
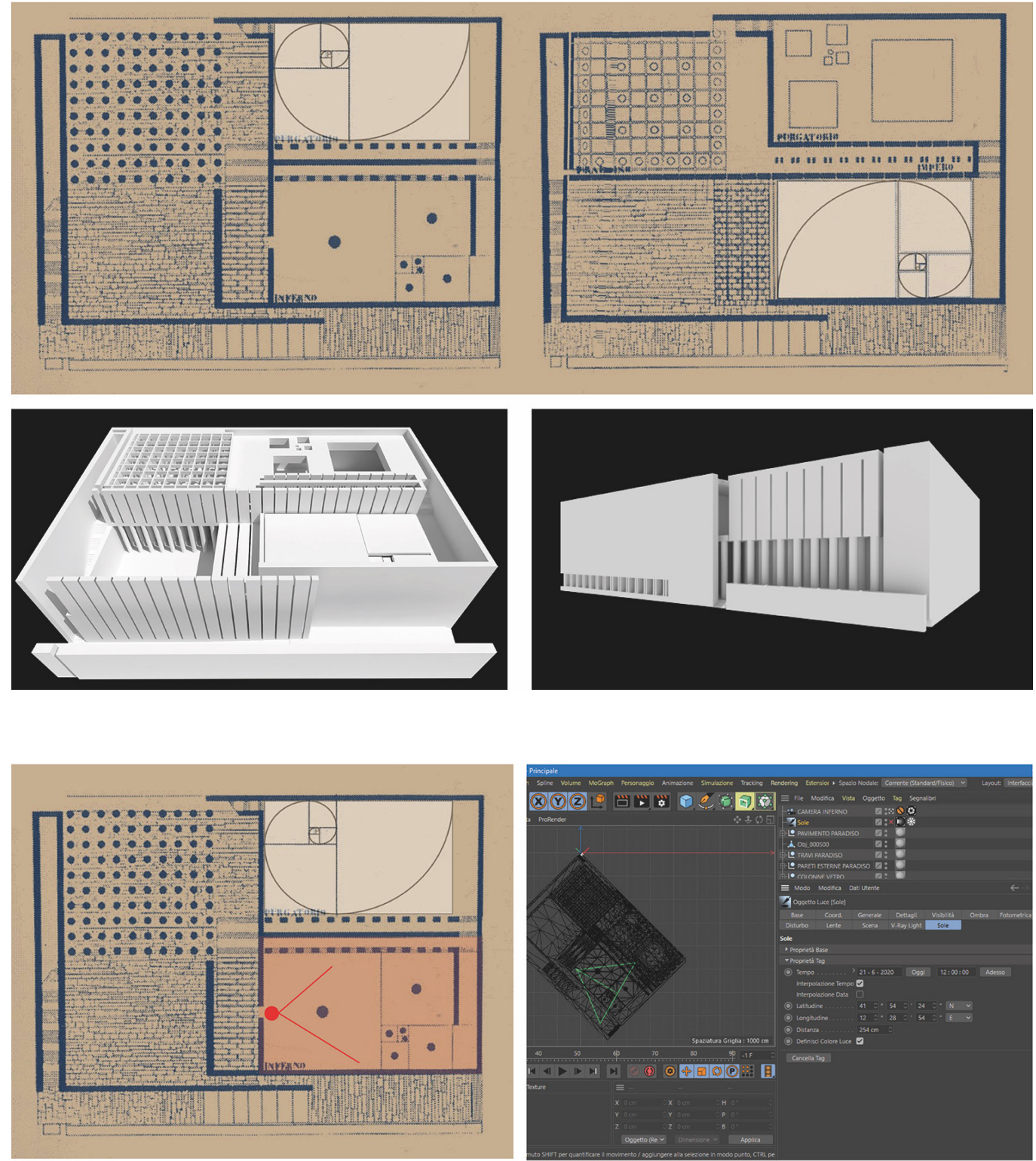

Fig. I I. Studio dell'illuminazione solare nella Sala dell'Inferno. Al centro: al solstizio estivo; in basso: al solstizio invernale al solstizio invernale (elaborazioni digitali di Mazzarano)
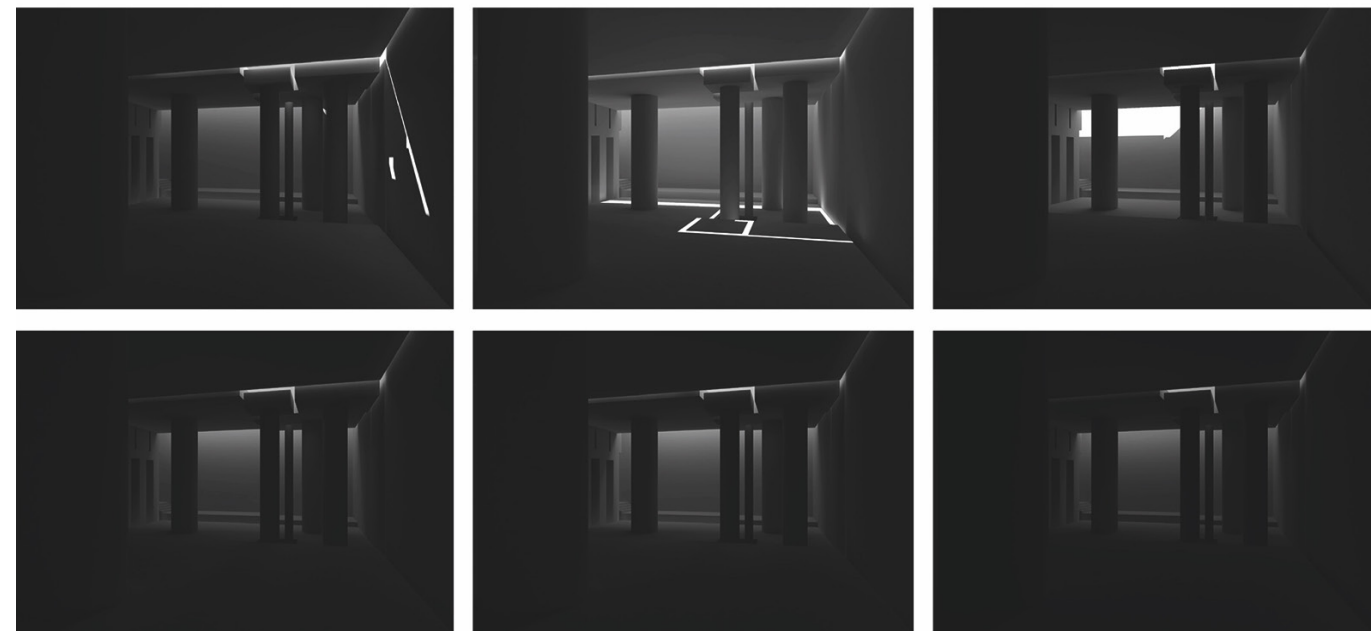
Fig. 12. Rendering finale della Sala del Paradiso (elaborazione digitale di Alex Dallatorre, Alessia Mazzarano).
Forse, alterando e spostando il nostro punto di vista, intrappolato per diverso tempo in una innaturale condizione statica, la pandemia ci ha portato a rimisurare e ripensare gli spazi della nostra quotidianità e, con essi, a riconsiderare e consolidare il ruolo del disegno come strumento potente capace di prefigurare scenari, in diverso modo lontani, e per narrarne i relativi contenuti.

In conclusione, ciò che di questa esperienza potrà sopravvivere anche dopo la fine dell'emergenza non è tanto nella metodologia della didattica a distanza che, come tutti speriamo, presto potrà tornare a svolgersi in presenza, quanto piuttosto al ritrovato interesse nei confronti di un disegno capace di verificare, attraverso simulazioni digitali, soprattutto la qualità degli spazi, misurata secondo diversi parametri e in cui anche i caratteri immateriali, come ad esempio la luce e la percezione in generale, assumono un ruolo fondamentale nella loro composizione.

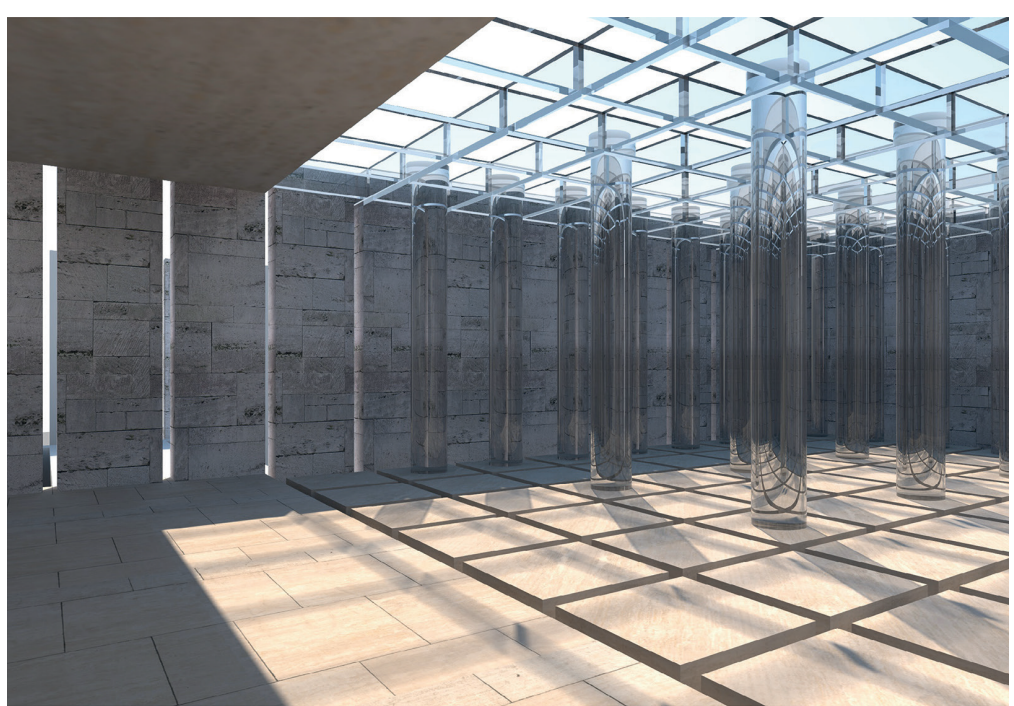

Note

[I] II corso al quale si fa riferimento nel testo è quello di Disegno tenuto dal prof. Giuseppe D'Acunto con la collaborazione dell'architetto Antonio Calandriello, tenuto presso l'Università luav diVenezia, CdS Magistrale in Architettura, A.A. 2020-2I .

[2] Agli studenti è stata lasciata libertà di scelta circa l'uso dei software, in quanto il corso voleva fornire degli strumenti teorici e metodologici in grado affinare la loro formazione all'interno di diversi ambienti digitali.

\section{Riferimenti bibliografici}

Chiaramonte G., Siza A. (20 I 8). La misura dell'Occidente. Viaggio nella rappresentazione. Roma: Postcart Edizioni.

D’Acunto G., Giordano A. (2017). Descrivere lo spazio - Dalla genesi geometrica alla rappresentazione delle superfici, vol. I. Padova: Edizioni il Progetto.

Pittaluga F. (20|4). Stanze di Luce. Roma: Aracne Editrice.

Pittaluga F., Scavuzzo G. (2007). Variazioni di luce in un interno. Roma: Aracne Editrice.

SchumacherT. L. (1983). Terragni e il Danteum 1938. Roma: Officina Edizioni.

\section{Autori}

Giuseppe D’Acunto, Università luav di Venezia, dacunto@iuav.it;

Antonio Calandriello, Università luav di Venezia, acalandriello@iuav.it

Per citare questo capitolo: D'Acunto Giuseppe, Calandriello Antonio (2021). Un 'disegno' alternativo: linguaggi, strumenti e metodologie di un'esperienza didattica ai tempi del Covid-19/An alternative 'drawing': languages, tools and methodologies of a teaching experience at the time of Covid-19. In Arena A.,Arena M. Mediati D. Raffa P. (a cura di). Connettere. Un disegno per annodare e tessere. Linguaggi Distanze Tecnologie. Atti del $42^{\circ}$ Convegno Internazionale dei Docenti delle Discipline della Rappresentazione/Connecting Drawing for weaving relationship. Languages Distances Technologies. Proceedings of the $42^{\text {th }}$ International Conference of Representation Disciplines Teachers. Milano: FrancoAngeli, pp. I525- I 544. 


\title{
An Alternative 'Drawing': Languages, Tools and Methodologies of a Teaching Experience at the Time of Covid-19
}

\author{
Giuseppe D'Acunto \\ Antonio Calandriello
}

Abstract

This essay arises from the need to share an unusual experience of a drawing course carried out totally remotely during the Covid-19 pandemic, within the educational offer of a master's degree course in Architecture.

This experience was immediately accepted as a challenge rather than an adversity and required a total rethinking of the contents and communication styles, rejecting the idea of adapting those already consolidated into the new didactic format.

Thus, this course embodied the desire to experiment and establish a new representative -and therefore cognitive- approach to architecture, identifying some representative procedures aimed at building complex digital models and communicating their values through 'images'.

Through the critical analysis of some paradigmatic case studies illustrated during the theoretical lectures and the communications offered by the professor and by scholars invited specially for this purpose, a broad overview of the critical studies and methodological approaches developed in recent years on the theme of the contribution of digital technology in architecture, both national and abroad, was offered as the theoretical premise for the experimental and laboratory phase.

In particular, there were three thematic areas discussed, both from a theoretical point of view and in the related exercises of the students: 'formal complexity', 'light and architectural space', and 'the architecture and its images'. Within these fields, as described in this essay, the students were able to experience and verify the power of architectural images within an articulated and complex narrative structure.

Keywords

digital modelling, digital photogrammetry, photo insertion, rendering.

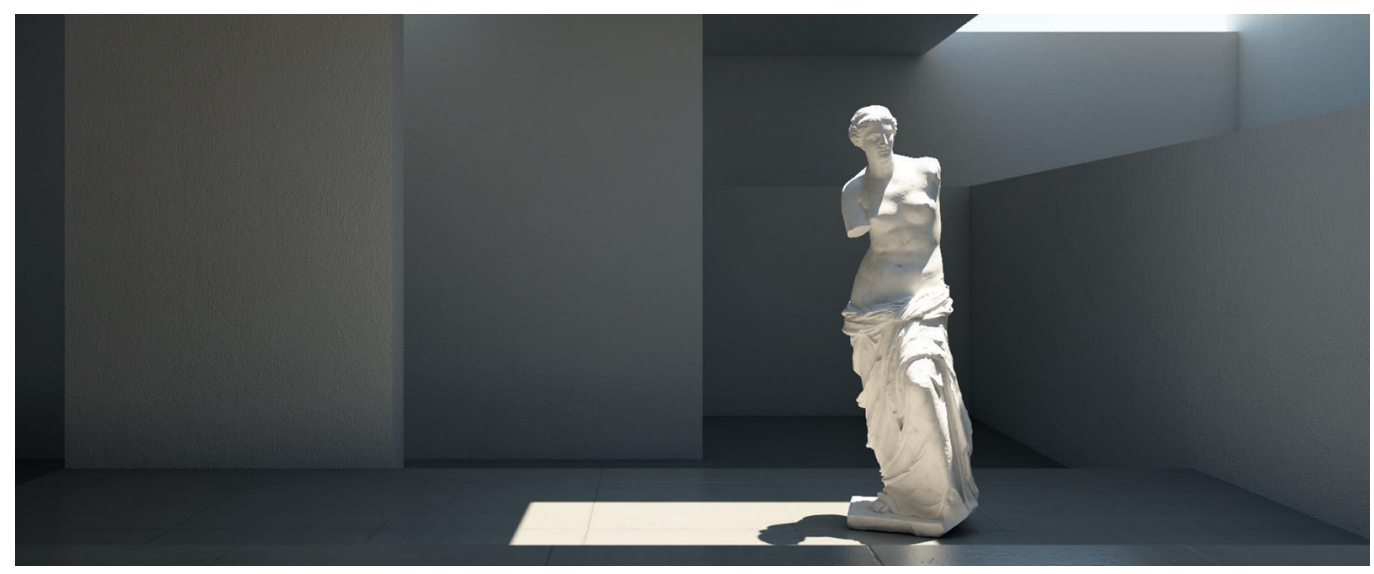


The teaching of drawing in its various definitions and declinations is perhaps the one that has adapted with the greatest difficulty to the remote modality that the last year has imposed on us due to the Covid-19 pandemic. Nevertheless, we have managed to provide several hours of drawing in the degree courses in which we are involved, inventing new forms of remote communication with our students based on communication styles different from the consolidated ones, always safeguarding the educational aims of the courses. In some cases, in addition to a different teaching methodology, our aim was to investigate and experiment with new topics of reflection and work which the lockdown has forced us to consider more carefully.

This essay stems from the need to share an unusual experience of a drawing course [I] carried out totally remotely within a master's degree course in Architecture, where the professor has never physically met the students, not even for the final exam, and where the results of the learners' work, paradoxically excellent or even better than those obtained in previous years in similar and face-to-face courses, have on one hand reassured about the success of this didactic experiment, but, on the other hand, have forced us to review our almost ideological positions and our profound reluctance towards the remote teaching of drawing.

The first challenge encountered in the planning of the course, knowing from the start that it would be held entirely remotely, was to rethink the contents, still firmly anchored to the educational aims of the teaching project, avoiding adapting to the unusual remote format the same contents already widely tested in previous years. Therefore, this course represented the desire to experiment and establish a new representative -and therefore cognitiveapproach to architecture, and its purpose was to identify some representative protocols aimed at building complex digital models and communicating their values through 'images'. Through the critical analysis of some paradigmatic case studies illustrated during the theoretical lectures and the communications offered by the professor and by scholars invited specially for this purpose, a broad overview of the critical studies and methodological approaches developed in recent years on the theme of the contribution of digital technology in architecture, both national and abroad, was offered as the theoretical premise for the experimental and laboratory phase.

Fig. I. Sequence of the operations for the creation of the polygona model with texture with the software Agisoft Metashape. From top to bottom and from left to right: uploading of the images, construction of the sparse points cloud, insertion of the markers creation of the dense cloud, creation dense cloud, creation of the texh model and of the tions (digital elaborations by Katharina Magi, Chiara Momet Rossetti).
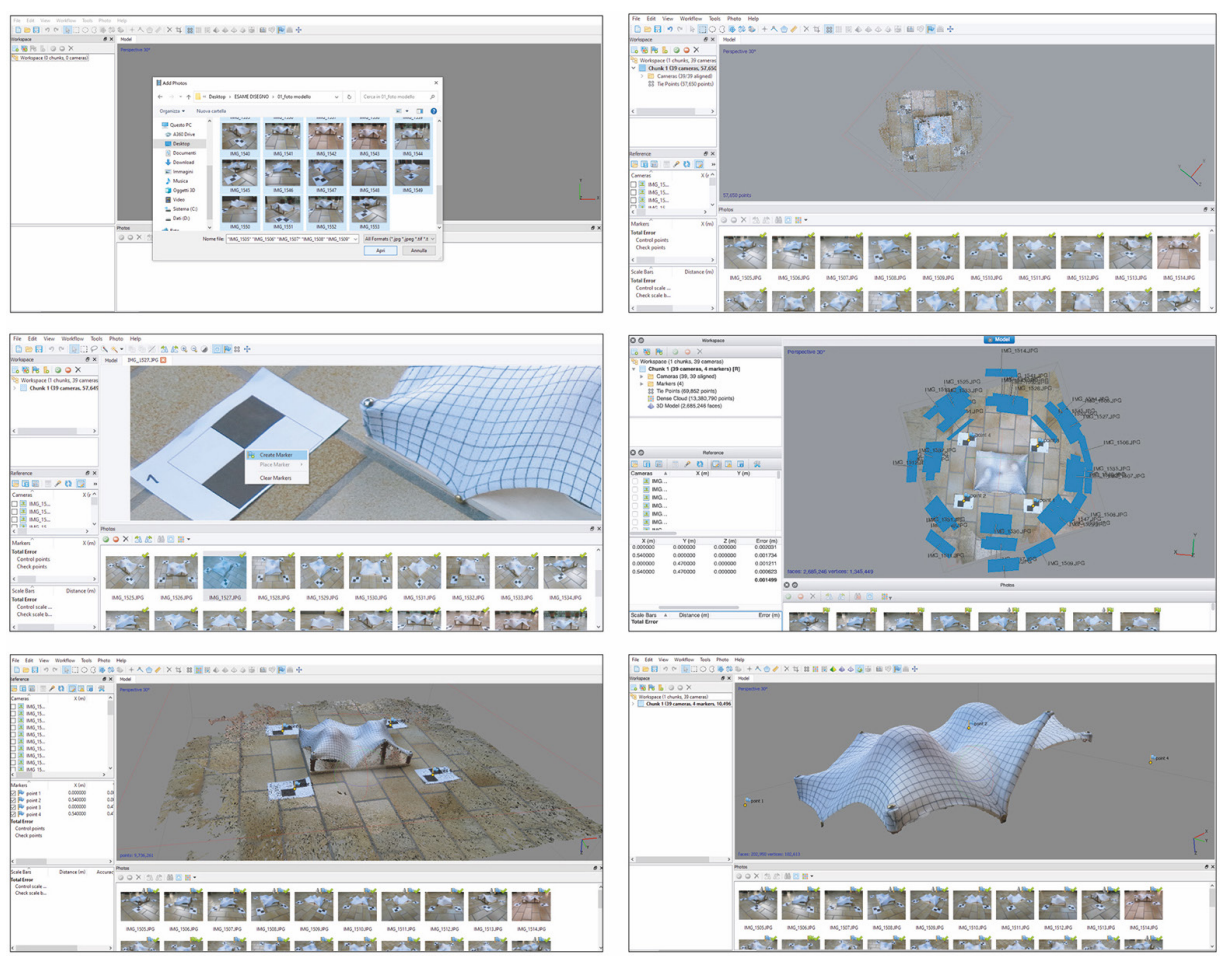
Fig. 2. Translation of the surface from the numerical to the mathematical model. From top to bottom and from left to right: import of the mesh model in Rhinoceros, regularisation of the mesh model, creation of the section curves, isolation of the section curves, intensification of the curves in the points of maximum curvature (digital elaborations by Katharina Magi

Chiara Mometti, Melissa Rossetti).
In particular, there were three thematic areas discussed, both from a theoretical point of view and in the related exercises of the students:' formal complexity', 'light and architectural space', and 'the architecture and its images'.

The theme of 'formal complexity' focused on the analysis of some examples of contemporary architecture to verify how the encounter between geometries, even non-traditional ones, and the digital modelling has stimulated the mind of architects to develop unprecedented inventive skills and formal experimentation.

The students, reflecting on these issues, were invited to verify and exercise their formal invention abilities by creating a physical model with a very complex geometric/formal configuration, then translating it into a digital model by means of digital photogrammetry and, subsequently, manipulating it in a virtual space with the tools of digital modelling to obtain an extremely complex architectural form. In this context, the important element is not the origin of the models used, but the possibility of translating them into electronic algorithms capable of digitally shaping an architectural form. Geometry, in its most complex theoretical meanings, is exactly the basis of this translation system. It is a design approach that intentionally reverses the creative and operational phases: the 'formal complexity' is shaped and articulated manually by the students with the aim of resuming a physical contact with the material and the body of architecture, to then pour it into a digital environment where it can be freely manipulated and transformed.
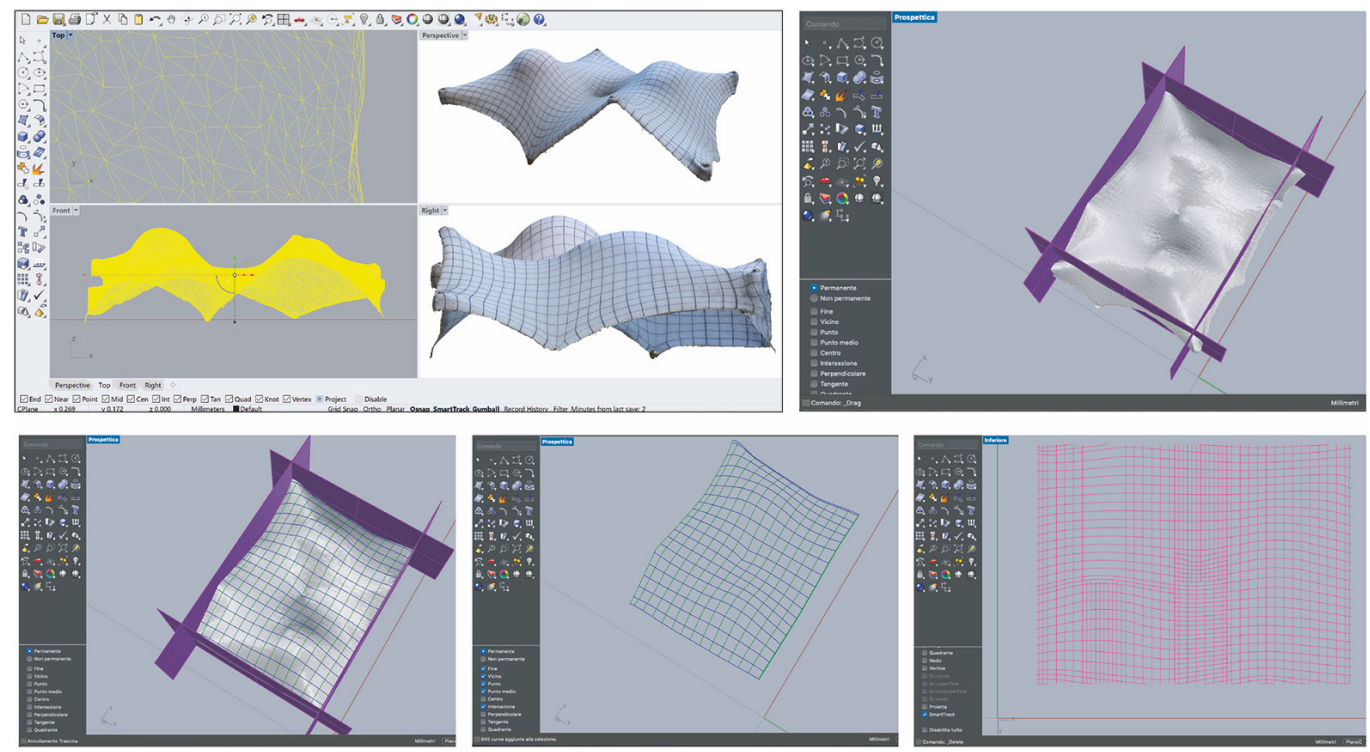

Students were then asked to physically model a freeform surface using an elastic fabric and simple 'modifier' elements (like drawing pins, wire, cardboard wood ribs) which simulated the forces acting on the surface. Once the desired shape was established, appropriate markers were affixed and then the surface was surveyed using digital photogrammetry. The photos, created respecting the rules of overlapping and spatial distribution imposed by the structure from motion (SfM) software, were processed using the software Agisoft Metashape, and then aligned. Subsequently, the coordinates of the markers were entered into the software to obtain a final model correctly oriented and metrically reliable. The choice of inserting the markers after the alignment is methodological: in this way, the software Metashape can automatically display the markers in each photo, and the user only has to confirm their position, quickening this procedure. Then, the sparse points cloud (the identification of homologous points, called tie points), the dense cloud, the polygonal mesh model and finally the texture were created from scratch (fig. I). 
Fig. 3. Translation of the surface from th numerical to the

mathematical mode rom top to bottom and from left to right: example of a section curve, reconstruction of the section curve, creation of the surface 'network': verification 'f the correspondence of between the starting mesh model (in light URBS surface NURBS surface (in grey) (digital elaborations

chiara Mometti, Melissa Rossetti).

Fig. 4. Tessellation of the NURBS surface with Paneling Tools of the software Rhino (elabosoftware Rhino (elaboration by Alex Dallatorre

Fig. 5. Tessellation of the NURBS surface with the software Grasshopper.

Above: the algorithm

used. Below: the phases

of subdivision of the

surface using the Vorono diagram (digital elaborations by Marco Bonotto, Anna Calia Di Pinto, Alessia Toniolo).
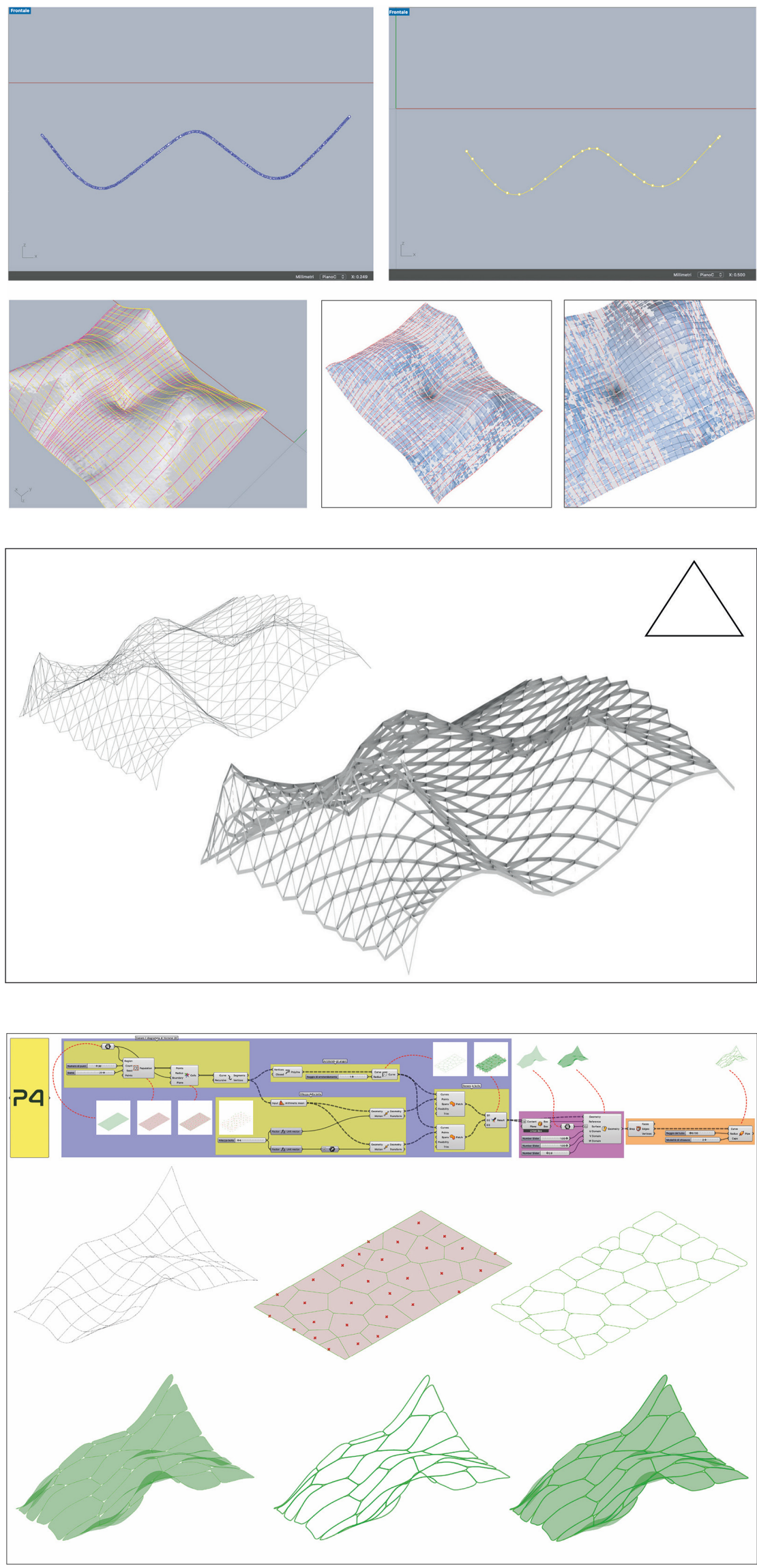
The model exported in .obj format together with its texture was imported into the digital space of the modelling software NURBS Rhinoceros. The mesh model was then cleaned up, and longitudinal and transverse sections were created through the command 'contour', intensifying them in the points of maximum curvature. These sections were then reconstructed manually with the command 'curves: interpolate points'. This strategy was preferred to an automatic process in order to obtain greater control over the distribution of the 'control points' of the curves and to intensify them where the radius of curvatures was minor (fig. 2). The reconstructed curves were used to generate the new NURBS surface through the command 'surface from network of curves' (fig. 3). This step helped the students to become aware of the different types of models (discrete, polygonal, mathematical) that can describe the same surface, their characteristics, and how they behave when subject to changes.

Finally, the model was tessellated using the paneling tools of the software Rhino, or Grasshopper in the most articulate cases. This step was particularly useful to make the surface polygonal once again and similar to an architectural structure (figs. 4, 5).

In the second phase of this first exercise, the students were invited to imagine inserting this complex form deriving from the process just described in a structured environment. Each student was then invited to choose a space defined by different functions and morphological characteristics (an urban space, an architectural intern, a physical place represented and controlled by a rigorous perspective) framed within a vertical image (pictorial or photographic) from which it was possible to uniquely obtain the perspective reference, then proceed to the perspective reconstruction, and finally to obtain the space and its various components represented in true form and size (fig. 6).

At this point, the digital model concerning the dimensions of the chosen space inside which the previously obtained tessellated surface was inserted was built. Thanks to the information obtained from the perspective reconstruction, it was possible to place the camera in the right spatial position (fig. 7). The verification of the correct focal length of the digital camera, where there is no such information, was carried out by positioning the image in semitransparency vertically on the ground line and in the centre of the projection (fig. 8). The model was then imported into Cinema4D or 3ds Max [2], the lights were set in accordance with the initial image, the chosen materials were applied, and eventually the

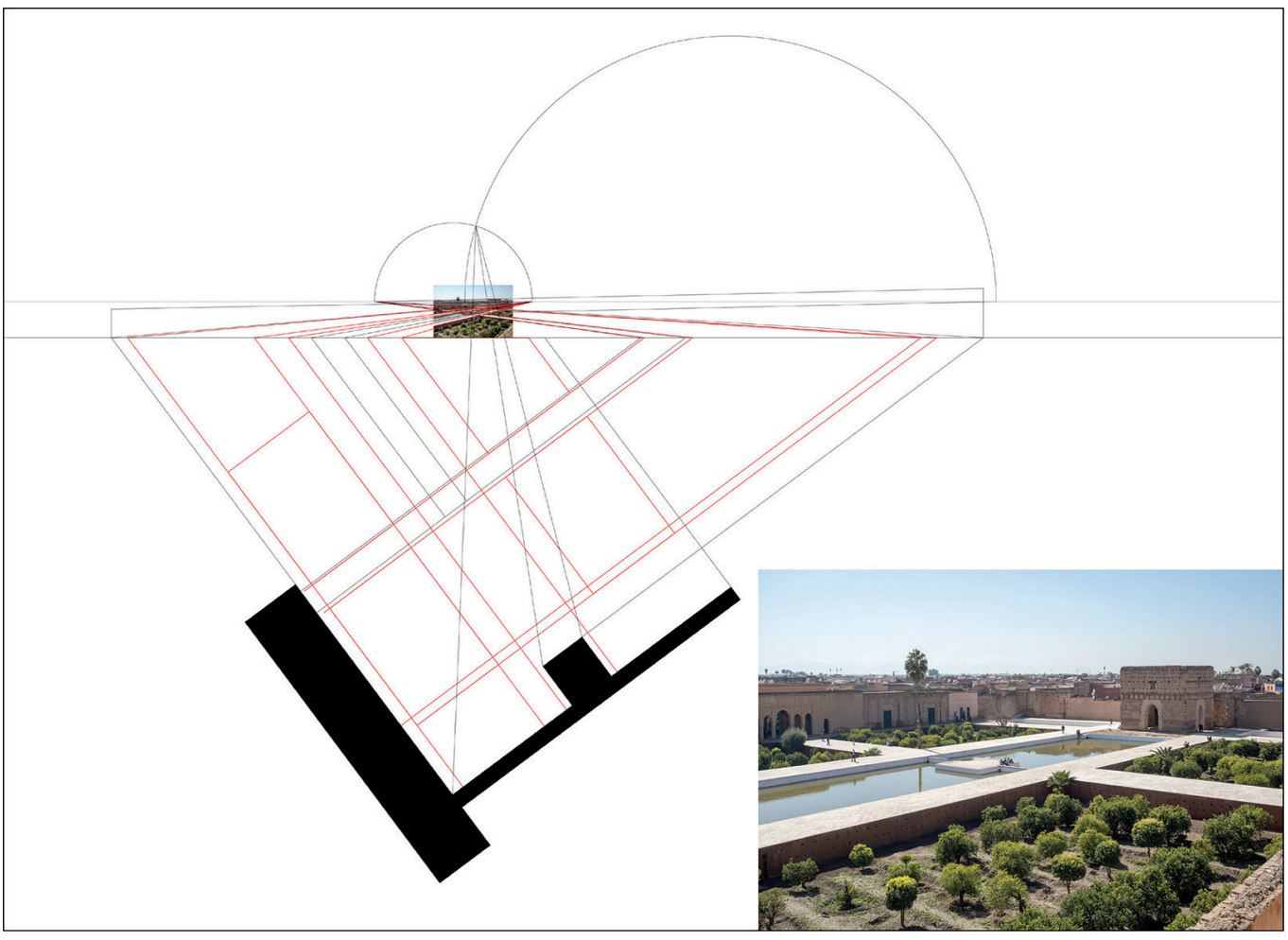


scene was rendered. Finally, the two images -that of the rendering and the starting onewere overlapped (fig. 9).

It was an extremely complex and fascinating exercise, considered from the very beginning as the perfect combination between a traditional working methodology -the perspective reconstruction - and the innovation of digital modelling and rendering. The ability to enter the most intimate structure of the chosen images, to reconstruct the space represented, to control it geometrically, and to find a perspective connection between the new inserted form and the already structured context was perceived and welcomed by the students as an exercise with a strong experimental and design feature and as a methodological approach. This approach, in its absolute geometric rigor, has avoided and removed any form of automatism in the construction phase of the overall image, the same uncritical automatism that too often characterises unsuccessful attempts at photo insertions.

The second part of the course, dedicated to the theme of the light, was inaugurated by the conference held by Franca Pittaluga, Professor of Architectural Design at the luav University of Venice, who showed the students the results of her long and passionate research focused on the role of natural light in the design of contemporary architectural spaces. The scholar presented an intense reflection on the light intended as a fundamental agent in the characterisation of spaces designed for human beings through history. Like other design tools (such as proportion, the articulation of the parts, the detail of the elements), natural light is assumed and studied as a quality vehicle that the architect puts into action to give the rooms a distinctive, sometimes unrepeatable, value. The studies of Pittaluga retrace the intentional action of designers, comparing spaces shaped by light and drawn by shadow to decode the architectural artifices that are at their origin. Depending on the cases, these latter refer to certain structural strategies, particular conformations of section, peculiar options on the envelope, or innovative experiments on materials [Pittaluga, Scavuzzo 2007; Pittaluga 20 I4]. Pittaluga's reflections represented an essential premise to the following exercise presented to the students. The modelling of the light was regulated by a critical and design approach which found an immediate digital verification in its relations with the different architectural configurations taken into account, and with the material and chromatic characterisations of the spaces.
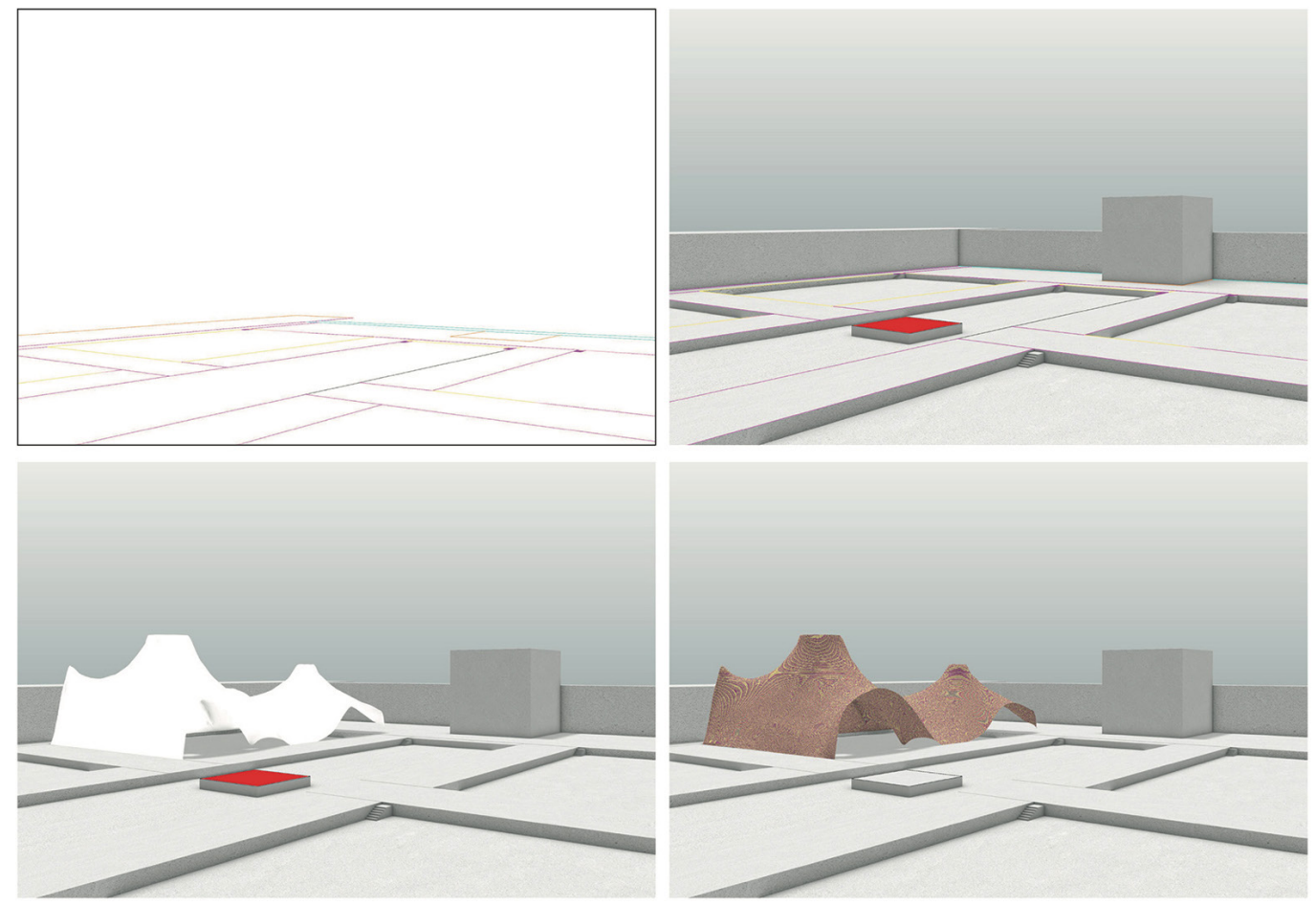
The students were basically asked to prefigure scenarios through renderings of architectural environments where the light played an important and essential role in the compositional organisation of the spaces. In many cases, the students preferred to focus their research on projects developed in other courses in order to verify the behaviour of the light in a digital simulation. Unusual and unexpected scenarios which, paradoxically, had only been imagined but had never happened in previous teaching experiences, opened up. In other cases, the students preferred to focus on the verification of the light in some spaces designed by contemporary architects but never built, leaving the issue of the light often unresolved.

It is the case of the Danteum, a tribute to Dante's Divine Comedy designed in 1938 by Giuseppe Terragni (1904-193) and Pietro Lingeri (1894-1968) but never built [Schumacher 1983]. It is a strongly symbolic work that evokes the main places of the Divine Comedy by the means of large spaces that had to convey their meaning through materials and architectural laws. In this phase, the students virtually recreated the architectural spaces and the set of lights corresponding to the solar one within the different rendering software used, taking into consideration the solar exposure and the location of the project. The analysis of the behaviour of the solar light also had a practical result, since it was a useful activity for the realisation of the final images (figs. I0, II).

Fig. 8. Verification of the perspective system and its final result (on the right), (digital elaborations by Alberto Baccini and Gaetano Sedicino).

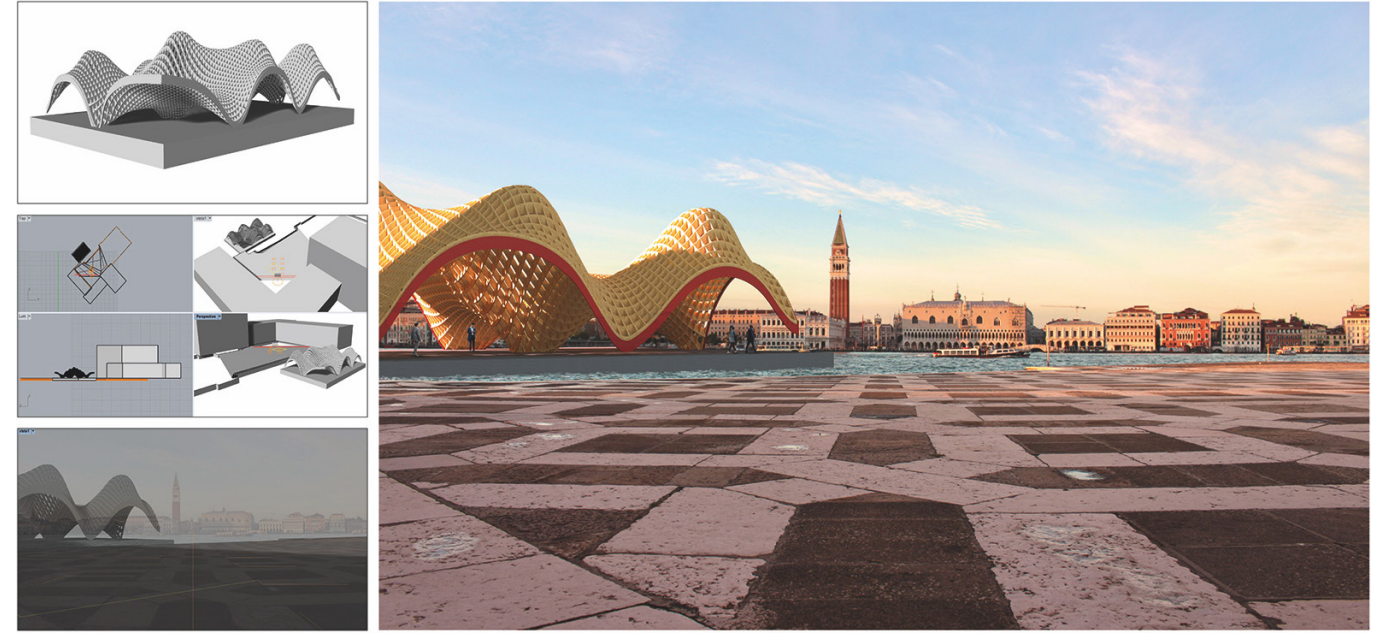

In the final part of the course, dedicated to The architecture and its images, the students were offered a reflection on architectural images and their ability to narrate the architectural design process, to highlight their relationship with the architect, to convey the expressive and formal values through overall and detailed views. In this sense, the subjective image, that of the dependent observer, was attributed a fundamental role in its multiple forms taken over the course of history, from the Renaissance perspective, to photography, and to current renderings. Thus, the construction of a virtual image was understood as and attributed an extraordinary means of prefiguration of a built space, moving away from any form of digital automatism to constitute itself as a 'new subjective image' with its own aesthetic status, and to therefore be linked to the photographic representations in the methodological system and in its expressive and communicative function. To underline this fundamental connection between two only apparently different methodological systems, and to make students accustomed to overlap the concept of rendering with that of authorial architectural photography, the experimental phase was preceded by an illuminating lecture by maestro Giovanni Chiaramonte. In his lecture, the famous photographer from Varese talked about his long experience alongside Alvaro Siza and his attempt to build a personal and intimate story of the Portuguese master's architecture through shots capable of framing and trapping the most profound meaning and significance of those forms in their relationship with light, matter, and space [Chiaramonte, Siza 20 I8]. 
In this phase the attention was focused on the use of the rendering software cameras (mainly Cinema4D and 3ds Max combined with the V-Ray rendering engine), on the importance of framing and on the appropriate use of the materials. The students, who had already studied and calibrated the lights, focused on the aspects linked to the matter and faced the difficult choice of the textures and the calibration of each parameter (such as, for example, bump, reflexion, and reflectance) that regulates the rendering of the materials. The students had also the opportunity to experiment with different materials than those of the initial projects, thus witnessing the sometimes-profound variation of the very essence of architecture (fig. I2).

Perhaps, by modifying and shifting our point of view, caught up in an unnatural static condition for too long, the pandemic has led us to remeasure and rethink the spaces of our everyday life and, with them, to reconsider and consolidate the role of drawing as a powerful tool capable of prefiguring otherwise distant scenarios and to narrate their contents.

In conclusion, what of this experience can survive, even when the emergency is over, is not the methodology of remote teaching that, as we all hope, will soon come to an end, but the renewed interest in a type of drawing able to verify, through digital simulations, the quality of spaces measured according to different parameters and in which even the immaterial features, such as the light and perception in general, play a fundamental role in their composition.
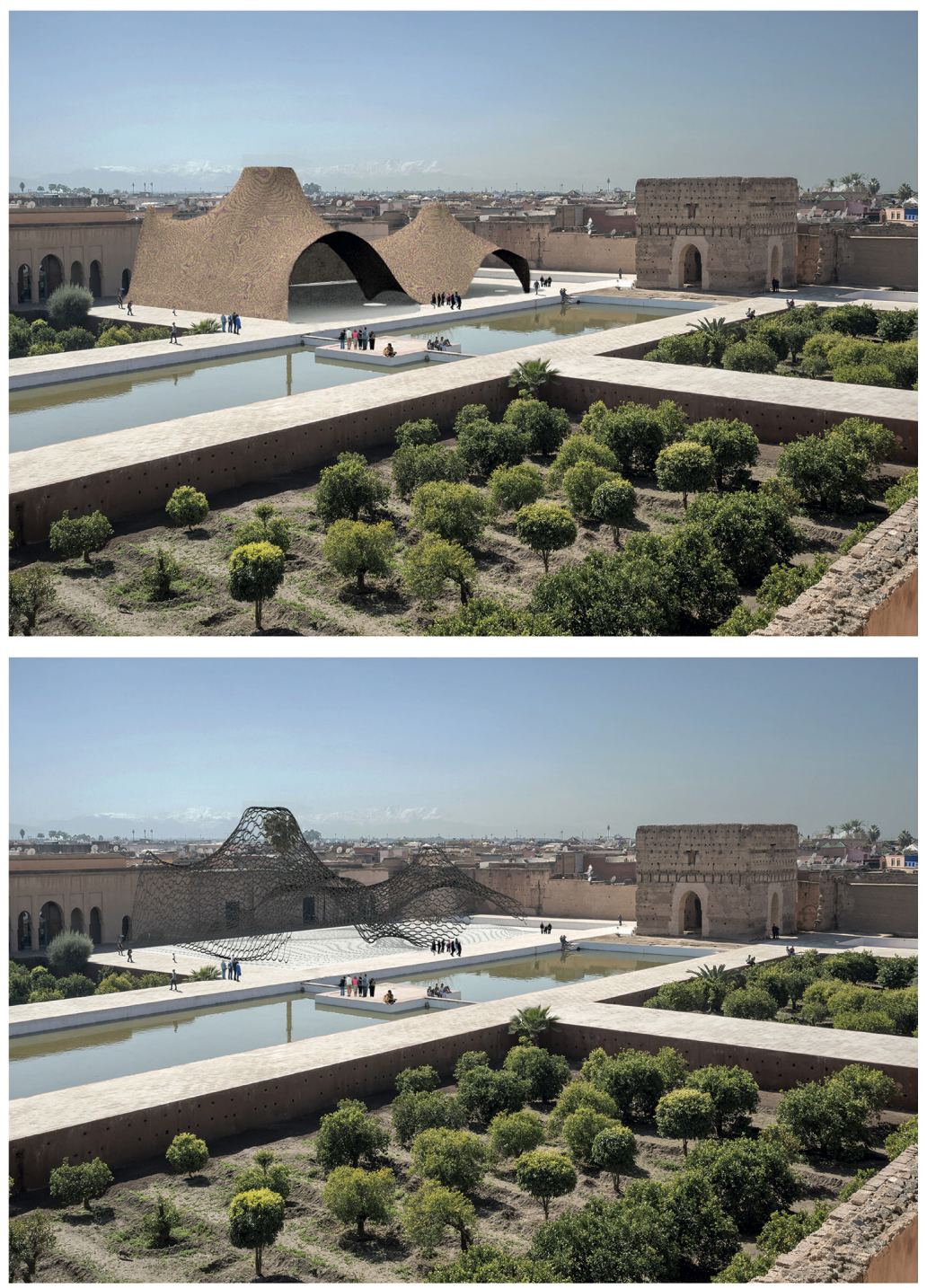
Fig. 10. Above: processing of archive images of th Danteum. Below: digita model (elaboration by Alex Dallatorre and Alessia Mazzarano).
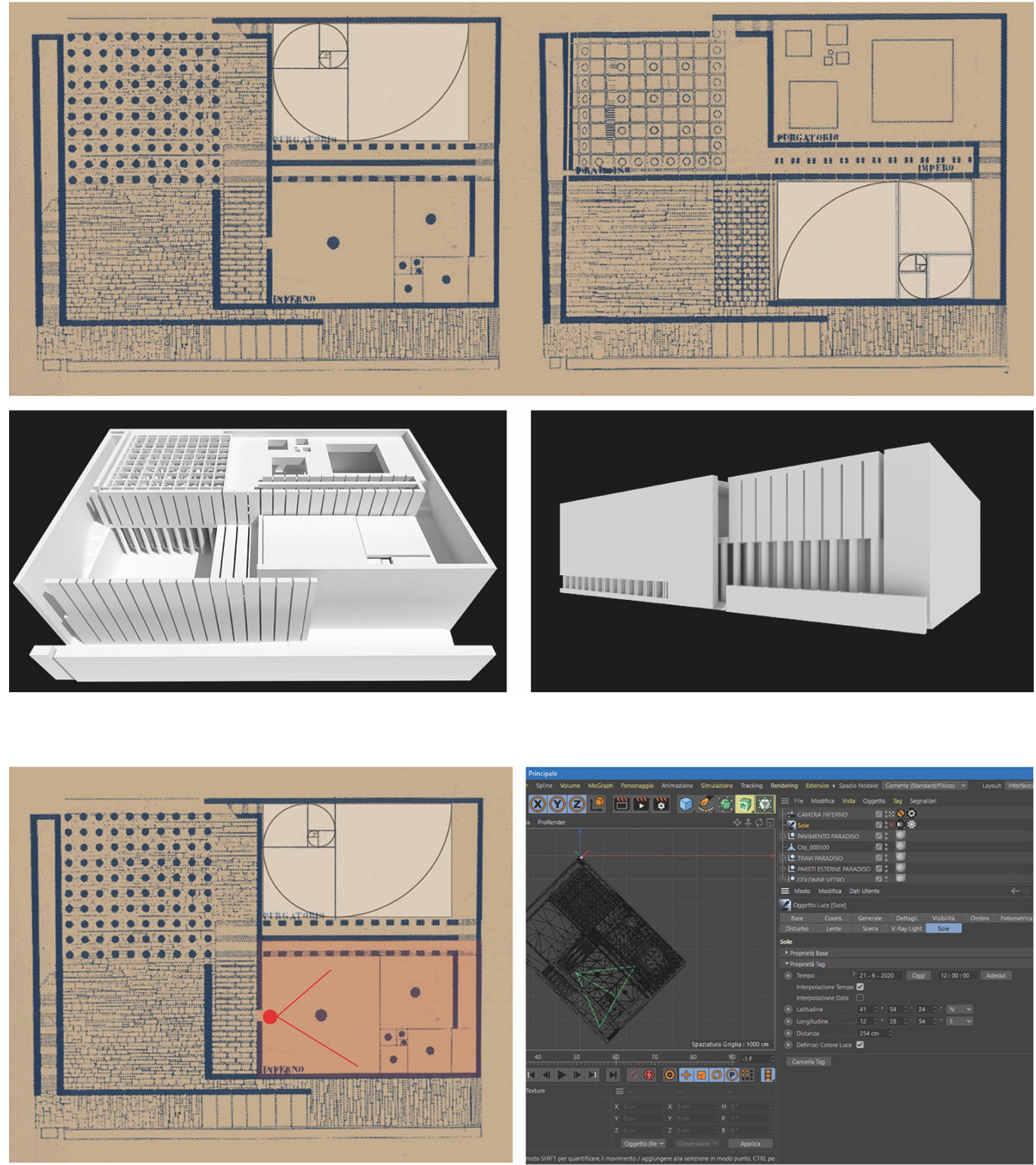

Fig. I I. Study of the solar illumination in the Salc dell'Inferno (Room of Hell). Centre: summer solstice. Below: winter solstice (digital elaborations by Alex Dallatorre and Alessia Mazzarano).
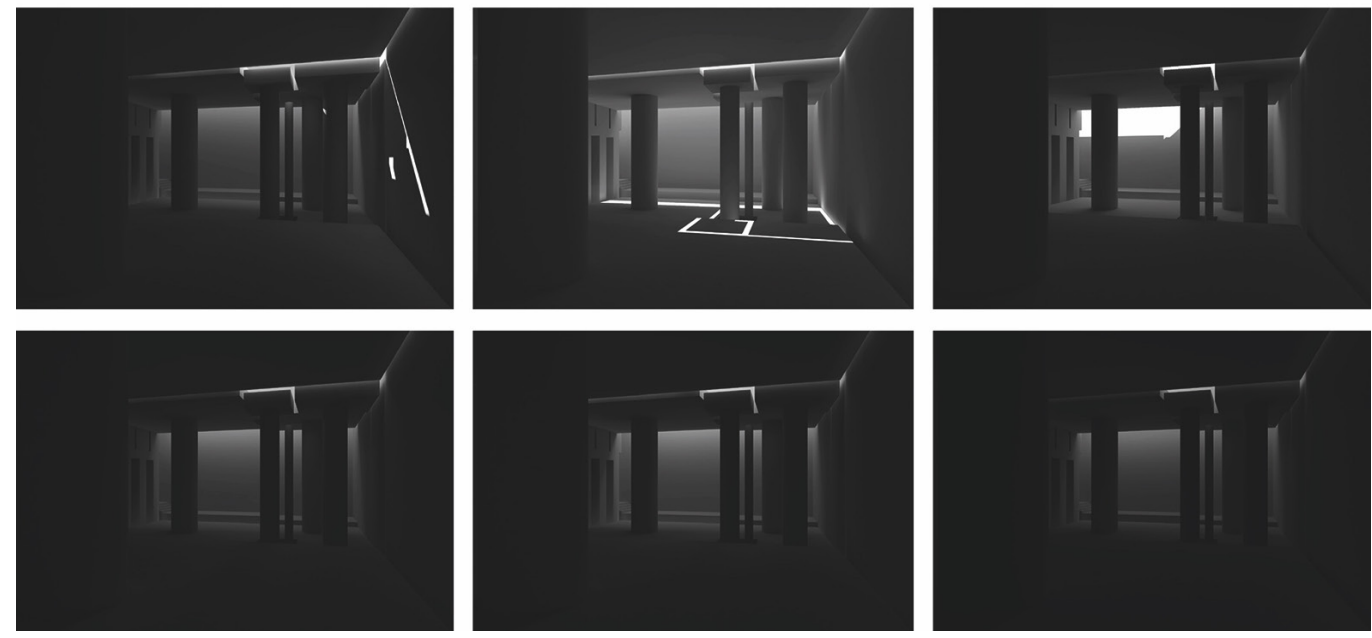
Fig. 12. Final rendering Of the Sala del Par (Room of Paradise), (elaboration by Alex Dallatorre and Alessia Mazzarano).

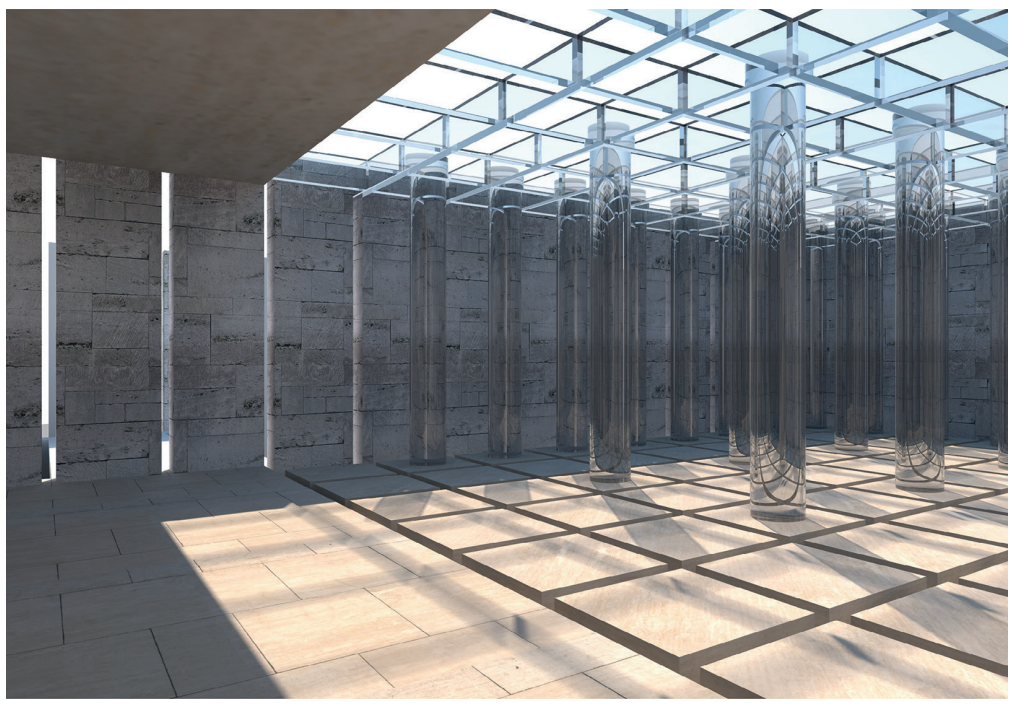

Notes

[I]The course referred to in the text is that of Drawing held by Professor Giuseppe D'Acunto with the collaboration of the architect Antonio Calandriello, held at the luav University of Venice, Master's Degree in Architecture, in the school academic year 2020-2I.

[2] The students were left free to choose the software, since the course aimed to give them the theoretical and methodological means that would enable them to refine their training within different digital environments.

\section{References}

Chiaramonte G., Siza A. (20 I 8). La misura dell'Occidente. Viaggio nella rappresentazione. Roma: Postcart Edizioni.

D'Acunto G., Giordano A. (2017). Descrivere lo spazio - Dalla genesi geometrica alla rappresentazione delle superfici, vol. I. Padova: Edizioni il Progetto.

Pittaluga F. (20|4). Stanze di Luce. Roma:Aracne Editrice.

Pittaluga F., Scavuzzo G. (2007). Variazioni di luce in un interno. Roma: Aracne Editrice.

SchumacherT. L. (1983). Terragni e il Danteum 1938. Roma: Officina Edizioni.

\section{Authors}

Giuseppe D'Acunto, Università luav di Venezia, dacunto@iuavit:

Antonio Calandriello, Università luav di Venezia, acalandriello@iuav.it

To cite this chapter. D'Acunto Giuseppe, Calandriello Antonio (2021). Un 'disegno' alternativo: linguaggi, strumenti e metodologie di un'esperienza didattica ai tempi del Covid- 19/An alternative 'drawing': languages, tools and methodologies of a teaching experience at the time of Covid-19. In Arena A. Arena M. Mediati D. Raffa P. (a cura di). Connettere. Un disegno per annodare e tessere Linguagoi Distanze Tecnologie Atti del $42^{\circ} \mathrm{Conveg}$ no Internazionale dei Docenti delle Discipline della Rappresentazione/Connecting. Drawing for weaving relationship. Languages Distances Technologies. Proceedings of the $42^{\text {th }}$ International Conference of Representation Disciplines Teachers. Milano: FrancoAngeli, pp. I525-I 544. 